\title{
Novel Achievements with an Old Metal: Copper-Promoted Synthesis of Four- Membered Azacycles
}

\author{
Benito Alcaide*a, Pedro Almendros ${ }^{*} \mathbf{b}$ and Amparo Luna ${ }^{a}$ \\ Received (in $X X X, X X X) X$ th $X X X X X X X X X 20 X X$, Accepted $X$ th $X X X X X X X X X 20 X X$ \\ ${ }_{5}$ DOI: $10.1039 / b 000000 x$
}

The synthesis of four-membered azacycles is of importance because of the chemical and biological relevance of these compounds. Recent progress in copper-catalyzed reactions has been applicable to a variety of research fields, such as heterocyclic synthesis. The aim of the current review is to summarize the synthesis of strained four-membered ring taking advantage of copper catalysis.

\section{${ }_{10}$ 1. Introduction}

A key point for chemical synthesis is efficiency, converting readily available starting materials into target molecules in relatively few operations and requiring minimal quantities of raw material and producing minimal waste. Therefore, the 15 development of reactions that achieve both selectivity and atom economy must be a prime goal of synthetic chemistry. The ability of transition metal salts to catalyze organic reactions constitutes one of the most powerful strategies to address these fundamental issues, having a significant impact both on academic research and 20 in industrial settings. Metal catalysis is widely employed in a variety of fields from the total synthesis of natural products to the preparation of new biomaterials or the preparation of large samples for clinical trials as well as for manufacturing. ${ }^{1}$ During the past few years the field has matured and at the same time 25 expanded into areas, which were rather unexplored before. Thus, a resplendent age of metal catalysis has bloomed in the last years. Although in the early 1900s Ullmann and Goldberg independently reported the first copper-promoted coupling reaction, ${ }^{2}$ an arylation of nucleophiles, probably because of the 30 harsh reaction conditions coupled to the normal use of stoichiometric amounts of copper salts, copper catalysis was not viewed as a viable alternative to the main classes of established metal catalysts until recently. Interestingly, a change in fortune for copper catalysis has come about as a result of the use of 35 additives that allowed the incorporation of catalytic amounts of copper under mild conditions. The copper- and palladiumcatalyzed reactions have been linked because both transition metals have been used for the construction of similar types of carbon-carbon and carbon-heteroatom bonds. ${ }^{3}$ However, in 40 several instances copper salts are complementary to palladium catalyst For example, in the arylation process of indoles, palladium shows a high selectivity for arylation at C-2 position ${ }^{4}$ and copper catalyzed exclusively at C-3 position. ${ }^{5}$ The site selectivity exhibited by both catalysts was orthogonal and this 45 kind of selectivity is one of the most difficult challenges in the field of carbon-hydrogen functionalization. Thus, the development of direct metal-catalyzed transformations that operate under ambient and selective reaction parameters is an attractive goal for the advancement of the chemical synthesis 50 using copper-based salts. ${ }^{6}$

On the other hand, chemical research of strained fourmembered azacycles, where a nitrogen atom is part of the ring, has become a highly dynamic area of international priority and importance in many fields of Science, including Organic ${ }_{55}$ Chemistry, Inorganic Chemistry, Medicinal Chemistry, and Material Science. ${ }^{7}$ In addition to being key scaffolds in natural products as well as in compounds of biological and industrial interest, the use of four-membered azacycles as starting materials to prepare many different substances justifies a long lasting effort 60 to work out new synthetic protocols. ${ }^{8}$ The aim of this review is to provide a survey of the types of copper-assisted reactions used to prepare four-membered azacycles, concentrating on the advances that have been made in the last decade.

\section{Synthesis of $\beta$-lactams}

65 2-Azetidinone ( $\beta$-lactam), a four membered cyclic amide (Figure 1) has been recognized as the fundamental pharmacophore group for a large number of bioactive compounds.

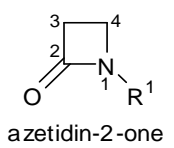

70 Figure 1. Structure of 2-azetidinone ( $\beta$-lactam).

The most important aspect of the synthesis of $\beta$-lactam derivatives has been the construction of the four-membered ring. $\beta$-Lactam antibiotics such as penicillins and cephalosporins have occupied a central role in the fight against pathogenic bacteria 75 and the subsequent rise in quality of life for the world population as a whole. ${ }^{9}$ In addition, there are many important nonantibiotic uses of 2-azetidinones in fields ranging from enzyme inhibition, some of the more notable advances concern the development of mechanism-based serine protease inhibitors of elastase, 80 cytomegalovirus protease, thrombin, prostate specific antigen, 
and cell metastasis and as inhibitors of acyl-CoA cholesterol acyl transferase to gene activation. ${ }^{10}$ It has also been reported that $\beta$ lactams act to modulate the expression of glutamate neurotransmitter transporters via gene activation. ${ }^{11}$ These 5 biological activities, combined with the use of these products as starting materials to prepare $\alpha$ - and $\beta$-amino acids, alkaloids, heterocycles, taxoids, and other types of compounds of biological and medicinal interest, ${ }^{12}$ provide the motivation to explore new methodologies for the synthesis of substances based on the $\beta$ 10 lactam core.

\subsection{Kinugasa reaction}

\subsubsection{General aspects of the Kinugasa reaction}

Among the different synthetic routes for the construction of the $\beta$-lactams, the Kinugasa reaction is a direct and simple method 15 that should be taken in consideration. The reaction offers several advantages, which include mild reaction conditions and the availability of a large repertoire of alkynes and nitrones. Crafting of these functionalities on two arms of the same molecule to facilitate an intramolecular reaction is comparatively easier than 20 the widely used Staudinger reaction, which requires the use of an acyl halide, a more reactive functionality. In 1972, Kinugasa and Hashimoto $^{13}$ first reported the reaction of copper (I) phenylacetylide with nitrones providing a facile way to synthesize $\beta$-lactams (Scheme 1). The reaction was carried out in 25 dry pyridine at room temperature under nitrogen atmosphere for 0.5-1 $\mathrm{h}$ and the cis-products were obtained exclusively in good yields (51-60\%). This process was the first Kinugasa-type synthesis of cis- $\beta$-lactams in stereoselective manner.

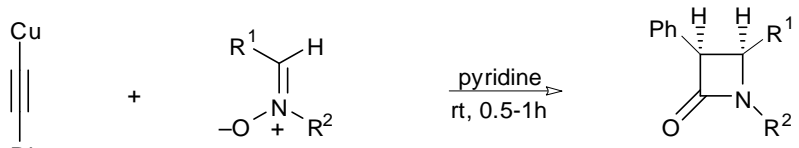

$$
\begin{aligned}
& 1 \quad 2 a R^{1}=R^{2}=P h \quad 3(51-60 \%) \\
& 2 \text { b R } \mathrm{R}^{1}=\mathrm{O}-\mathrm{MeC}_{6} \mathrm{H}_{4}, \mathrm{R}^{2}=\mathrm{Ph} \\
& \text { 2c } \mathrm{R}^{1}=0-\mathrm{ClC}_{6} \mathrm{H}_{4}, \mathrm{R}^{2}=\mathrm{Ph} \\
& \text { 2d } \mathrm{R}^{1}=\mathrm{Ph}, \mathrm{R}^{2}=\mathrm{p}-\mathrm{ClC}_{6} \mathrm{H}_{4}
\end{aligned}
$$

30 Scheme 1. Synthesis of $\beta$-lactam ring through Kinugasa reaction.

In 1976 Ding and Irwin ${ }^{14}$ studied different nitrones and copper acetylides and discovered that a mixture of cis- and trans- $\beta$ lactams was always obtained in different ratios. The cis- $\beta$-lactam $\mathbf{3}$ was the major diastereomer in most cases and it was converted 35 in the trans-isomer $\mathbf{4}$ under basic conditions through an epimerization process. This isomerisation process also depends on the type of substituent at $C_{3}$ position (Scheme 2).

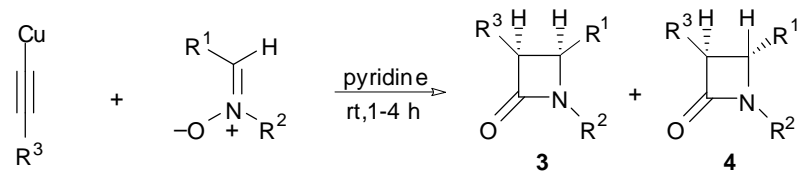

$$
\begin{aligned}
& \text { 1a } R^{3}=P h \quad \text { 2a } R^{1}=R^{2}=P h \\
& 2 \mathbf{b ~ R}^{1}=\mathrm{O}-\mathrm{MeC}_{6} \mathrm{H}_{4}, \mathrm{R}^{2}=\mathrm{Ph} \\
& \text { 3a: } \mathbf{4 a}(32 \%, d r=5: 3) \\
& \text { 2e } \mathrm{R}^{1}=\mathrm{p}-\mathrm{MeC}_{6} \mathrm{H}_{4}, \mathrm{R}^{2}=\mathrm{Ph} \\
& \text { 3b:4b }(25 \%, d r=10: 1) \\
& 3 e: 4 e(40 \%, d r=4: 1) \\
& \begin{array}{ll}
\text { 1b } R^{3}=B u & \text { 2a } R^{1}=R^{2}=P h \\
& \text { 2f } R^{1}=p-(M e O) C_{6} H_{4}, R^{2}=P h
\end{array} \\
& \text { 3f: }: 4 f(66 \%, d r=12: 1) \\
& \mathbf{3 g}: \mathbf{4 g}(25 \%, \mathrm{dr}=12: 1) \\
& \text { 1c } \mathrm{R}^{3}=\mathrm{CO}_{2} \mathrm{Et}_{2} \text { 2e } \mathrm{R}^{1}=\mathrm{p}-\mathrm{MeC}_{6} \mathrm{H}_{4}, \mathrm{R}^{2}=\mathrm{Ph} \\
& \text { 3h:4h }(51 \%, d r=3: 1) \\
& \text { 1d } \mathrm{R}^{3}=\mathrm{Hmp} \quad 2 \mathrm{~g} \mathrm{R} \mathbf{R}^{1}=\mathrm{p}-\mathrm{ClC}_{6} \mathrm{H}_{4}, \mathrm{R}^{2}=\mathrm{Ph} \\
& 1 e \mathrm{R}^{3}=\mathrm{Epa} \\
& \text { 3i:4i }(50 \%, d r=1: 1) \\
& 3 \mathbf{j}: 4 \mathbf{j}(75 \%, d r=1: 1)
\end{aligned}
$$

Scheme 2. Synthesis of $\beta$-lactam ring by Ding and Irwin.

40 These authors proposed the first mechanism for the Kinugasa reaction which is still accepted today (Scheme 3).
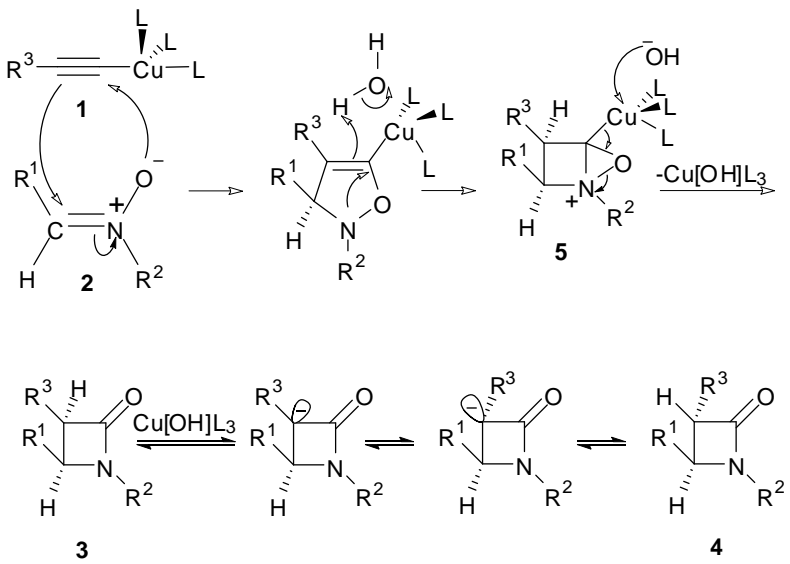

Scheme 3. Possible reaction pathway for the Kinugasa reaction as proposed by Ding and Irwin.

45 According to the mechanism proposed by Ding and Irwin, Chmielewski ${ }^{15}$ explained that the Kinugasa reaction involves a cycloaddition-rearrangement cascade process catalyzed by copper (I) ions and proceeds in the presence of an organic base. The initially formed copper-alkyne $\pi$-complex undergoes 50 deprotonation. Next, the activated triple bond takes part in a 1,3dipolar cycloaddition with a nitrone to provide five membered isoxazoline A. The rearrangement of isoxazoline copper complex $\mathbf{A}$ into copper enolate $\mathbf{B}$ and subsequent protonation leads to the formation of the $\beta$-lactam ring. The protonation of intermediate 55 enolate $\mathbf{B}$ in the second step occurs from the less-shielded side of the $\beta$-lactam ring (Scheme 4). 


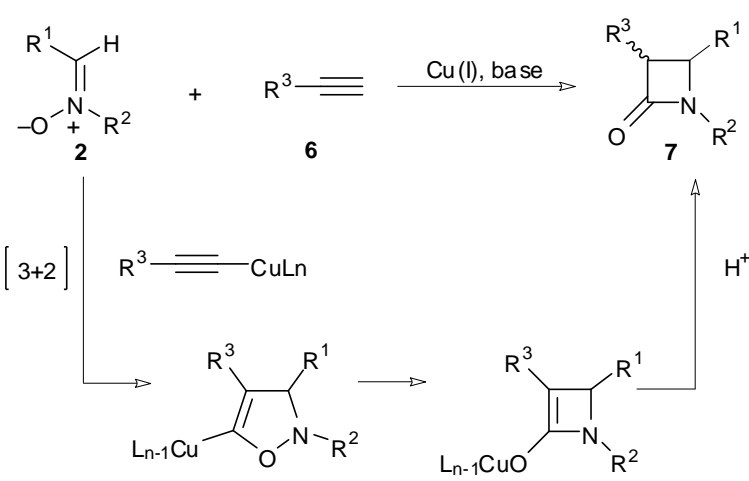

A
Scheme 4. Proposed mechanism of the Kinugasa reaction by Chmielewski.

Miura et al. ${ }^{16}$ developed the first catalytic version of this 5 reaction and found that the coupling reactions between a terminal alkyne and $C, N$-diarylnitrones could be accomplished with a catalytic amount of copper (CuI) and potassium carbonate (Scheme 5). The yields of the resulting products 3a, 4a, 8-10 were dependent on the type of phosphanes or nitrogen-containing 10 compounds used as ligands. In the absence of ligands or with ligands containing phosphane, such as triphenylphosphane, tributylphosphane, 1,2-bis(diphenylphosphanyl)ethane (dppe), 1,3-bis(diphenylphosphanyl)propane (dppp), or 2,2 -bipyridine, the trans- $\beta$-lactam $\mathbf{4 a}$ was isolated as the only product but in poor 15 yield. When the reaction was achieved in the presence of pyridine or 1,10-phenanthroline as ligands, the yields of the $\beta$-lactams were improved (55-71\%), and a mixture of cis-3a and trans-4a isomers in a 2:1 ratio for pyridine and in a 1:1.2 ratio for 1,10phenanthroline was obtained respectively.

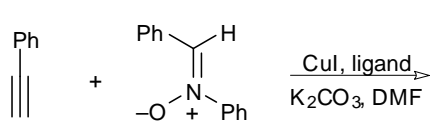

$6 a$<smiles>O=C1[C@H](c2ccccc2)[C@H]1c1ccccc1</smiles>

$3 a$<smiles>O=C1[C@H](c2ccccc2)[C@H](c2ccccc2)N1c1ccccc1</smiles>

$4 a$
20<smiles>O=C(O)Cc1ccccc1</smiles>

Scheme 5. Asymmetric intermolecular Kinugasa reaction developed by Miura.

In 2009, Pezacki and col. ${ }^{17}$ reported studies of simultaneous 25 micelle and copper-catalyzed multicomponent Kinugasa reaction in water (Scheme 6). The multicomponent process proceeds by a two-step reaction sequence involving the micelle-promoted nitrone formation from substituted benzaldehydes 11 and $\mathrm{N}$ phenylhydroxyl amine 12 followed by the in situ 1,3-dipolar 30 cycloaddition and rearrangement reaction with $\mathrm{Cu}$ (I) phenylacetylide. This reaction provided cis and trans $\beta$-lactams 13 with high yields (46-82\%) and the side amide 14 (11-36\%).

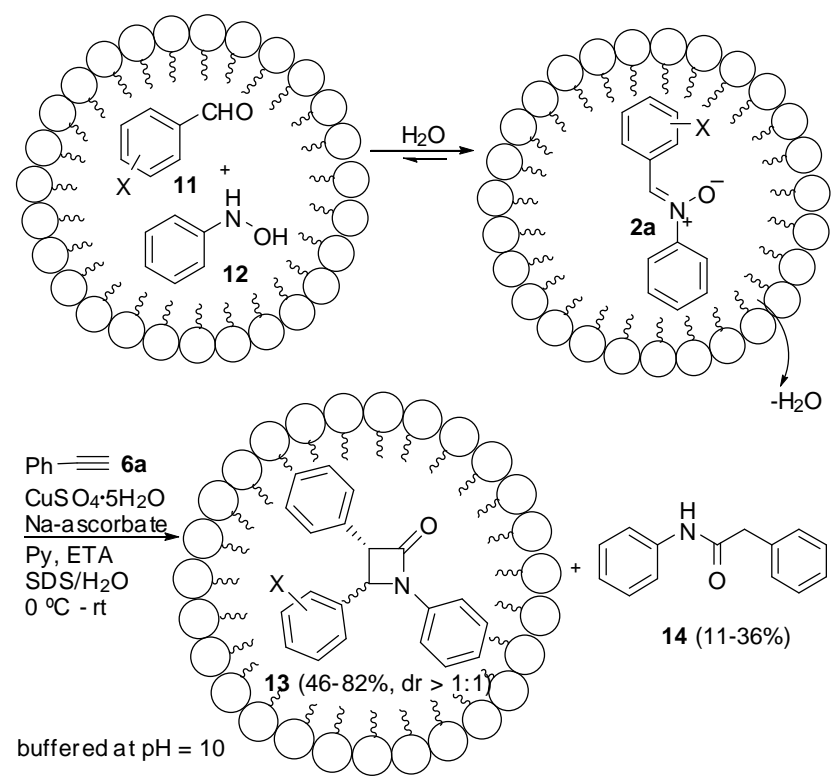

35 Scheme 6. Micelle-promoted multicomponent Kinugasa reaction.

The $\beta$-lactam nucleobase chimeric molecules have been prepared from the corresponding propargyl nucleobases via Kinugasa reaction mimicking the click chemistry conditions. ${ }^{18}$ The reaction was carried out with $\mathrm{CuSO}_{4} \cdot 5 \mathrm{H}_{2} \mathrm{O}$, which was 40 pretreated with sodium ascorbate in a mixture of $\mathrm{DMF} / \mathrm{H}_{2} \mathrm{O}, \mathrm{Et}_{3} \mathrm{~N}$ at $0{ }^{\circ} \mathrm{C}$. The presence of $\mathrm{L}$-ascorbate is essential because the reaction did not work in its absence. The click conditions worked really well and the $\beta$-lactams could be obtained in up to $71 \%$ yield (Scheme 7). 
<smiles>C#CCn1cnc2c(N)ncnc21</smiles>

15a $2 a \quad 3 k(71 \%, d r=1: 1)$<smiles>C#CCn1ccc(=O)[nH]c1=O</smiles><smiles>C#CCn1cc(C)c(=O)[nH]c1=O</smiles>

i) $\mathrm{CuSO}_{4} 5 \mathrm{H}_{2} \mathrm{O}, \mathrm{H}_{2} \mathrm{O}$, so dium ascorbate, rt. ii) Then DMF, Ar, $0{ }^{\circ} \mathrm{C}-\mathrm{rt}, \mathrm{Et}_{3} \mathrm{~N}, 16-25 \mathrm{~h}$.

Scheme 7. $\beta$-lactam nucleobase chimeric molecules prepared under click conditions.

\subsubsection{Intermolecular asymmetric Kinugasa reaction}

5 2.1.2.1 Asymmetric Kinugasa reaction using chiral catalysts

In another report, Miura et al. ${ }^{19}$ described the first examples of the asymmetric intermolecular Kinugasa reaction with chiral bisoxazoline-type ligands (Figure 2). When compound 16a was used as ligand, the reaction of alkyne $\mathbf{6 a}$ with nitrone $\mathbf{2 a}$ provided $\beta$ 10 lactams 3a and $\mathbf{4 a}$ in $45 \%$ yield ( $\mathrm{dr} 35: 65$ ) and $e e=40 \%$ for each isomer. The ee improved (68\%) when the amount of $\mathrm{CuI}$ was increased (1 mmol). Compounds $\mathbf{1 6 b}$ and $\mathbf{1 7}$ generated similar products with ees of $67 \%$ and $45 \%$, respectively. The slow addition of phenylacetylene $\mathbf{6 a}$ to a mixture of nitrone $\mathbf{2 a}$, CuI $15(0.1 \mathrm{mmol})$, and 16a $(0.2 \mathrm{mmol})$ afforded a $57 \%$ ee. Under the same reaction conditions and catalysts $\mathbf{1 6 b}$ or $\mathbf{1 7}$, copper(I) phenylacetylide precipitated preventing further reaction.

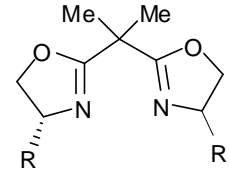

$16 a \mathrm{R}=\mathrm{i}-\mathrm{Pr}$ $16 \mathrm{~b} R=\mathrm{t}-\mathrm{Bu}$

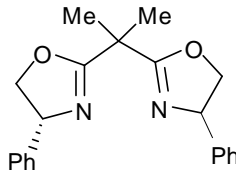

17
Figure 2. Bis-oxazoline-type ligands for asymmetric intramolecular 20 Kinugasa reaction.
The first versatile system for the copper-catalyzed asymmetric coupling of alkynes with nitrones using a chiral-ligand strategy was developed by Lo and $\mathrm{Fu} .{ }^{20}$ This group examined the utility of the Kinugasa reaction using a new $C_{2}$-symmetric planar-chiral 25 bis(azaferrocene) ligand and the sterically hindered base $N, N$ dicyclohexylmethylamine under Miura`s conditions (Scheme 8). However, the reaction between phenylacetylene 6a and $N$ - $\alpha$ diphenyl-substituted nitrones 2 in the presence of 19a and catalytic amounts of copper(I) chloride revealed a moderate 30 stereoselection. But, a methyl-substituted ligand 19b afforded the $\beta$-lactams 18 with excellent cis diastereoselectivity (95:5) and good ees (from 77 to $89 \%$ ), irrespective of the nature of the aromatic ring. The best results were obtained when 4-anisyl substituent (standard $N$-protecting group for $\beta$-lactams) was used.

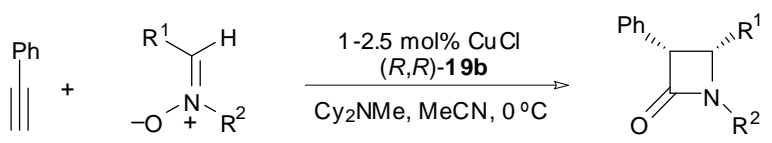

6a $\quad 2 a R^{1}=R^{2}=P h$

$$
\text { 2j } R^{1}=P h, R^{2}=p-(M e O) C_{6} H_{4}
$$

$2 \mathbf{k} \mathrm{R}^{1}=\mathrm{R}^{2}=\mathrm{p}-(\mathrm{MeO}) \mathrm{C}_{6} \mathrm{H}_{4}$

2I $R^{1}=\mathrm{Cy}, \mathrm{R}^{2}=\mathrm{p}-(\mathrm{MeO}) \mathrm{C}_{6} \mathrm{H}_{4}$

$18 \mathbf{a}(69 \%$, ee $=77 \%, d r=95: 5)$

18b $(53 \%$, ee $=85 \%$, dr $=95: 5)$

$18 \mathrm{c}(46 \%$, ee $=83 \%, \mathrm{dr}=93: 7)$

18d $(57 \%$, ee $=89 \%, d r=93: 7)$

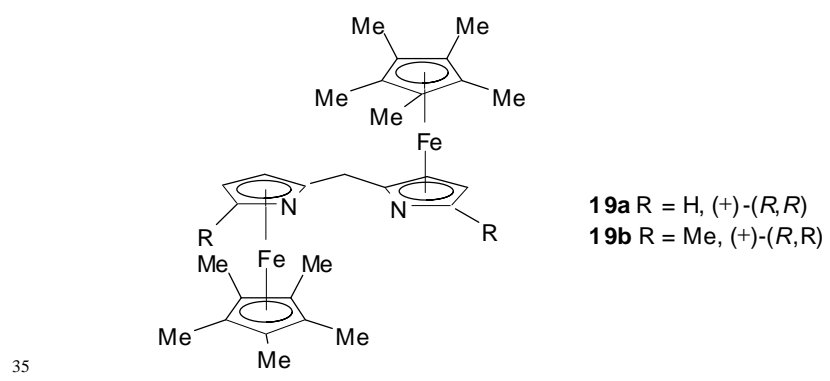

Scheme 8. Catalytic asymmetric synthesis of $\beta$-lactams by a chiral bis(azaferrocene) ligand.

Until now, Kinugasa reaction was performed strictly under 40 nitrogen atmosphere in order to mitigate the Glaser oxidative coupling. Tang and col. ${ }^{21}$ developed a superior catalyst, which is cheap, easy to access, air-stable and water-tolerant. They designed a pseudo $C_{3}$-symmetric trisoxazoline (TOX) 20 by sidearm approach and found that TOX $20 / \mathrm{Cu}(\mathrm{II})$ complex could 45 catalyze Kinugasa reaction very well. Moreover, they demonstrated in their study that the amines strongly influenced in the Kinugasa reaction for selectivity and yield. Although primary amines, secondary amines and tertiary amines promote this reaction; the best results have been obtained when a bulkier 50 amine (dicyclohexylamine) was used as base. When the reaction was carried out between a variety of structurally different nitrones and alkynes in the presence of a catalytic amount of $20 / \mathrm{Cu}\left(\mathrm{ClO}_{4}\right)_{2} \cdot 6 \mathrm{H}_{2} \mathrm{O}$ and $\mathrm{Cy}_{2} \mathrm{NH}$ in acetonitrile at $0{ }^{\circ} \mathrm{C}$, the desired cis- $\beta$-lactams 3 were achieved in good and moderate yields and 55 enantioselectivities. Later on, ${ }^{22}$ these authors synthesized a variety of trisoxazolines based on the frameworks of bisoxazolines in order to improve the asymmetric induction (Scheme 9) and they conclude that the best results were obtained with iPr-trisoxazoline $\mathbf{2 0} / \mathrm{Cu}\left(\mathrm{ClO}_{4}\right)_{2} \cdot 6 \mathrm{H}_{2} \mathrm{O}$. This method provided 60 a facile access to $\beta$-lactams in moderate yield and in moderate to good diastereo- and enantioselectivity. Besides, a copper (II) salt 
was an efficient catalyst for the first time in the Kinugasa reaction. In the following years, much effort has been dedicated to improve the stereoselectivity. For this reason, they also studied $^{23}$ the influence of the sidearm group and a series of chiral 5 oxazoline moieties was introduced into the IndaBOX scaffold in order to obtain a novel TOX/copper catalyst.

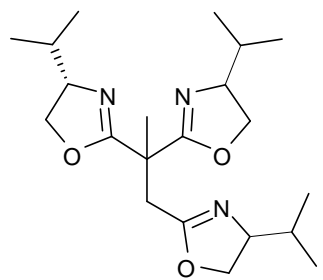

TOX-20

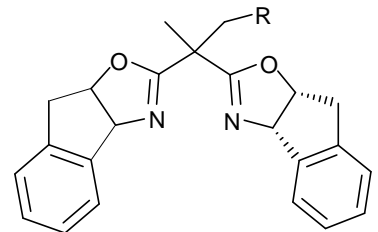

TOX-21
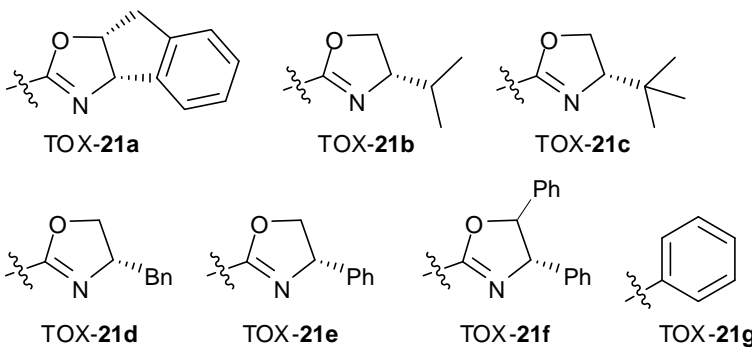

Scheme 9. Ligands studied by Tang research group.

The tert-butyl substituted TOX 21c/CuOTf-Tol showed the 10 fast reaction and higher cis-enantioselectivity. Compared with trisoxazoline/Cu(II) complex 20, the reaction with the $\mathrm{TOX} / \mathrm{Cu}(\mathrm{I})$ catalytic system 21c gave the best results in diastereo- and enantioselectivity (Scheme 10).

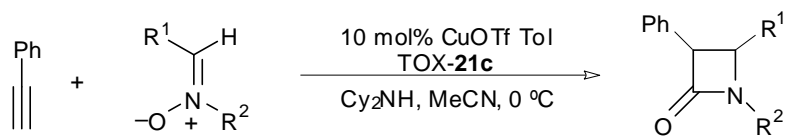

6a $\quad 2 a R^{1}=R^{2}=P h$

2j $\mathrm{R}^{1}=\mathrm{Ph}, \mathrm{R}^{2}=\mathrm{p}-(\mathrm{MeO}) \mathrm{C}_{6} \mathrm{H}_{4}$

$2 m R^{1}=P h, R^{2}=p-\left(E_{2} \mathrm{CO}_{2}\right) \mathrm{C}_{6} \mathrm{H}_{4}$

2n $\mathrm{R}^{1}=\mathrm{p}-\left(\mathrm{F}_{3} \mathrm{C}\right) \mathrm{C}_{6} \mathrm{H}_{4}, \mathrm{R}^{2}=\mathrm{Ph}$

15

Scheme 10. Synthesis of $\beta$-lactams by a pseudo $C_{3}$-symmetric trisoxazoline (TOX) 21c.

Otani and co-workers ${ }^{24}$ performed the Kinugasa reaction using a commercially and cheaply available $C_{2}$-symmetric IndaBox 20 ligand 22. This group of research studied different catalysts, bases, nitrones and alkyne substituents. The best results were obtained using $\mathrm{Cu}(\mathrm{OTf})_{2}$ and di-sec-butyl-amine $\left(\mathrm{s}-\mathrm{Bu}_{2} \mathrm{NH}\right)$ at 5 ${ }^{\circ} \mathrm{C}$. The Kinugasa reaction with different substituents in the alkyne component $\mathbf{6}$ and nitrone 2a was explored. The electron25 donating $p$-tolyl and $p$ - $\mathrm{MeOC}_{6} \mathrm{H}_{4}$ groups showed a high enantioselectivity and the cis-isomer was the major product. In contrast, the much more electron-withdrawing substituent $p$ $\mathrm{NO}_{2} \mathrm{C}_{6} \mathrm{H}_{4}$ preferred the trans-isomer (Scheme 11).

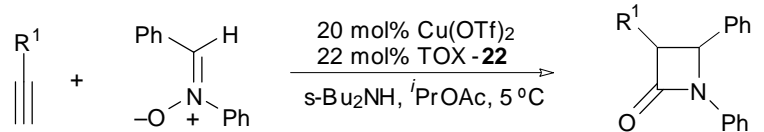

$2 a$

$6 \mathbf{a} \mathrm{R}^{1}=\mathrm{Ph}$

6b R ${ }^{1}=\mathrm{p}-\mathrm{MeC}_{6} \mathrm{H}_{4}$

$6 c \mathrm{R}^{1}=\mathrm{p}-(\mathrm{MeO}) \mathrm{C}_{6} \mathrm{H}_{4}$

6d R ${ }^{1}=p-\left(\mathrm{NO}_{2}\right) \mathrm{C}_{6} \mathrm{H}_{4}$

3a $(47 \%$, ee $=90 \%, d r=85: 15)$

$3 q(38 \%$, ee $=93 \%, d r=63: 37)$

$3 r(40 \%$, ee $=94 \%, d r=83: 17)$

3s $(51 \%$, ee $=86 \%, d r=18: 82)$

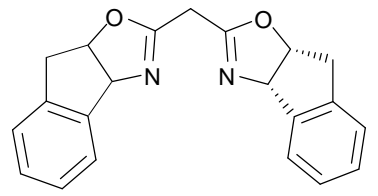

TOX-22

30 Scheme 11. Kinugasa reaction using a $C_{2}$-symmetric IndaBox ligand 22.

Recently, Feng and col. $^{25}$ described a new chiral diamine-Cu(OTf $)_{2}$ complex for the catalytic asymmetric Kinugasa reaction. Furthermore, the reaction was performed on pure water without the need of any organic co-solvents. In 35 contrast to most enantioselective Kinugasa reactions, this mild and operationally simple method provides a one-step route to optically active trans- $\beta$-lactams $\mathbf{2 3}$ in good yields, enantioselectivities and diastereoselectivities. This procedure tolerates a relatively wide range of substrates (electron-deficient 40 or electron-rich nitrones and electron-deficient or electron-rich phenylacetylenes). The trans isomer $\mathbf{2 3}$ is the result of isomerization at the $C_{3}$ position under the basic reaction conditions used (Scheme 12). Due to these excellent results, the synthetic potential of this catalytic system was evaluated for 45 gram-scale reactions, and the corresponding trans $\beta$-lactams 23 were obtained without any loss in reactivity and enantioselectivity.

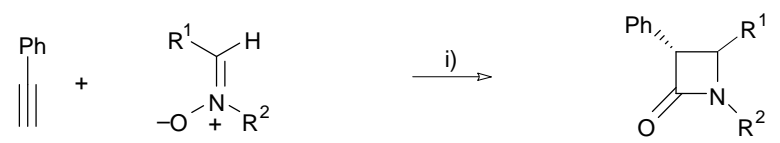

6a $2 \mathrm{~m} \mathrm{R} \mathrm{R}^{1}=\mathrm{Ph}, \mathrm{R}^{2}=\mathrm{p}-\left(\mathrm{EtO}_{2} \mathrm{C}\right) \mathrm{C}_{6} \mathrm{H}_{4} \quad$ 23a $(90 \%$, ee $=91 \%, \mathrm{dr}=99: 1)$

2o $\mathrm{R}^{1}=p-\mathrm{ClC}_{6} \mathrm{H}_{4}, \mathrm{R}^{2}=\mathrm{p}-\left(\mathrm{EtO}_{2} \mathrm{C}\right) \mathrm{C}_{6} \mathrm{H}_{4} \quad$ 23b $(75 \%$, ee $=93 \%, \mathrm{dr}=>99: 1)$

$2 p \mathrm{R}^{1}=p-\mathrm{BrC}_{6} \mathrm{H}_{4}, \mathrm{R}^{2}=\mathrm{p}-\left(\mathrm{EtO}_{2} \mathrm{C}\right) \mathrm{C}_{6} \mathrm{H}_{4} \quad$ 23c $(70 \%$, ee $=92 \%, \mathrm{dr}=>99: 1)$

$2 q R^{1}=P h, R^{2}=p-M_{e} C_{6} H_{4} \quad$ 23d (63\%, ee $\left.=90 \%, d r=63: 37\right)$

$2 r R^{1}=P h, R^{2}=m-C l C_{6} H_{4}$

23e $(56 \%$, ee $=92 \%, d r=90: 10)$

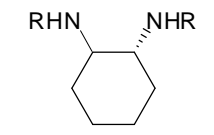

$24 \mathrm{R}=$ cycloheptanyl

i) $20 \mathrm{~mol} \% 24,10 \mathrm{~mol} \% \mathrm{Cu}(\mathrm{OTf})_{2}, \mathrm{n}-\mathrm{Bu}_{2} \mathrm{NH}$, water, $20^{\circ} \mathrm{C}$.

Scheme 12. Asymmetric Kinugasa reaction on water.

50 Basak developed a novel Kinugasa reaction using nitrones 2a and $\mathbf{2 h}$ and propargyl alcohol $\mathbf{2 5}$ in the presence of $\mathrm{CuI}$ and $\mathrm{L}$ proline in DMF at room temperature (Scheme 13). ${ }^{26}$ The reaction afforded two products, the cis- $\beta$-lactams 3 along with the 3 exomethylene $\beta$-lactams 26. When DMSO was uses as solvent, 55 the exomethylene adduct $\mathbf{2 6}$ became the major product. The presence of the amphoteric L-proline molecule is important for this one-step reaction sequence. The authors suggest the 
possibility that methylene $\beta$-lactams $\mathbf{2 6 a}$ and $\mathbf{2 6 \mathbf { b }}$ are derived from cis- $\beta$-lactams $3 \mathbf{t}$ and $\mathbf{3 u}$ by simple $\beta$-elimination. This process must have occurred during the formation of the $\beta$-lactam ring and not after.

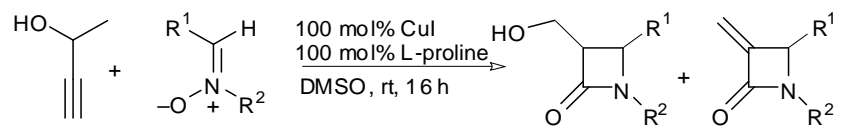

$$
\begin{aligned}
& 25 \quad 2 a R^{1}=R^{2}=P h \quad 3 t(10 \%) \quad 26 a(71 \%) \\
& \text { 2h } R^{1}=\text { furyl, } R^{2}=P h \\
& \text { 3u (10\%) 26b (70\%) }
\end{aligned}
$$

Scheme 13. Kinugasa reactions in presence of L-proline.
Azetidinyl $\gamma$-lactam-based peptides were synthesized by a 10 Kinugasa reaction of pyroglutamate $\mathbf{2 7}$ with diphenyl nitrone 2a. ${ }^{27}$ This reaction produced three diastereomers: one trans isomer $4 \mathbf{k}$ and a pair of cis isomers $3 \mathbf{v}$ and $\mathbf{1 8 e}$. It appears that only one of the cis isomers $\mathbf{1 8 e}$, epimerized to the trans compound and the other cis isomer $\mathbf{3 v}$ is configurationally more 15 stable and is resistant to epimerization. These kinds of products were excellent starting materials for the preparation of peptides 4l, 3w and $\mathbf{1 8 f}$ (Scheme 14). The synthesis of the peptides was carried out both with pure trans isomer and with the mixture of two cis isomers. Interestingly, the $\gamma$-lactam peptides showed a 20 preference for the $\beta$-turn conformation.

\subsubsection{Asymmetric Kinugasa reaction using chiral alkynes}<smiles>C#CCN1C(=O)CCC1C(=O)OCC</smiles>

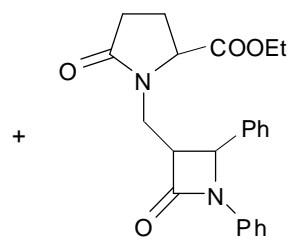

3v<smiles>CCOC(=O)C1CCC(=O)N1C[C@@H]1C(=O)N(c2ccccc2)[C@H]1c1ccccc1</smiles>

$18 \mathrm{e}$ i) $\mathrm{Et}_{3} \mathrm{~N}, \mathrm{Cul}, \mathrm{MeCN}, 4 \mathrm{~h}, \mathrm{rt}$, ii) $\mathrm{LiOH}, \mathrm{THF}-\mathrm{H}_{2} \mathrm{O}, 6 \mathrm{~h}, \mathrm{rt}$. iii) 28, EDC. $\mathrm{HCl}, \mathrm{HOBT}$, DMAP, $\mathrm{CH}_{2} \mathrm{Cl}_{2}, 6 \mathrm{~h}, 0^{\circ} \mathrm{C}$.<smiles>[NH3+]CC(=O)N[C@@H](Cc1ccccc1)C(=O)O</smiles><smiles>O=C(CNC(=O)C1CCC(=O)N1CC1C(=O)N(c2ccccc2)[C@H]1c1ccccc1)N[C@@H](Cc1ccccc1)C(=O)OC(c1ccccc1)c1ccccc1</smiles>

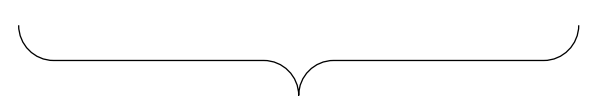

4I<smiles>O=C(CNC(=O)C1CCC(=O)N1CC1C(=O)N(c2ccccc2)C1c1ccccc1)N[C@@H](Cc1ccccc1)C(=O)OCc1ccccc1</smiles>

$3 w$<smiles>O=C(CNC(=O)C1CCC(=O)N1C[C@H]1C(=O)N(c2ccccc2)[C@H]1c1ccccc1)N[C@@H](Cc1ccccc1)C(=O)OCc1ccccc1</smiles>

$18 f$

Scheme 14. Azetidinyl $\gamma$-lactam-based peptides synthesized using a Kinugasa reaction for the construction of the four-membered ring.

In 2008, Hsung`s research group ${ }^{28}$ described a highly stereoselective synthesis of chiral $\alpha$-amino- $\beta$-lactams through an 25 ynamide-Kinugasa reaction. The reaction was carried out in the presence of $\mathrm{CuCl}$ in $\mathrm{MeCN}[0.2 \mathrm{M}]$ at room temperature. The reaction produced $\beta$-lactam cis-18g as the major isomer and the minor isomer was assigned as trans-4m (Scheme 15). An application of this reaction conditions was the preparation of 30 chiral $\alpha$-amino- $\beta$-lactams $\mathbf{1 8 j}$ and $\mathbf{4 p}$ in good yields. In this process, the high stereoselective observed requires both the initial cycloaddition and subsequent protonation (Scheme 16).<smiles>C#CN1C(=O)OC[C@H]1Br</smiles>

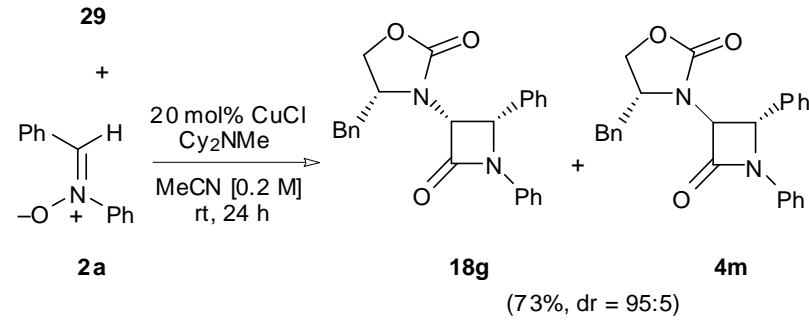

Scheme 15. Highly stereoselective ynamide Kinugasa reaction. 
<smiles>O=C1[C@@H](N2C(=O)O[C@H](c3ccccc3)[C@H]2Br)[C@H](Cl)N1[18O]</smiles>

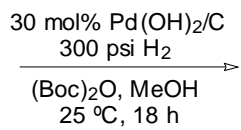

$18 \mathrm{~h}$<smiles>[CH][C@@H]1[C@@H](NC(=O)OC(C)(C)C)C(=O)N1[Pb]</smiles>

18i (96\%)

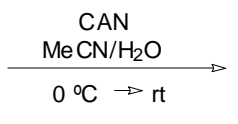<smiles>[CH]C1NC(=O)[C@H]1NC(=O)OC(C)(C)C</smiles>

18j (77\%) $\mathrm{DBU}$, toluene $110^{\circ} \mathrm{C}, 40 \mathrm{~h}$<smiles></smiles>

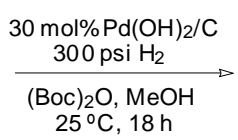
$25^{\circ} \mathrm{C}, 18 \mathrm{~h}$

4n (96\%)

Scheme 16. Synthesis of chiral $\alpha$-amino- $\beta$-lactams.

A novel approach for the synthesis of cholesterol absorption inhibitor ezetimibe $\mathbf{2 3 h}$ was developed by the group of ${ }_{5}$ Chmielewski. ${ }^{29}$ The key step in the synthesis is a Kinugasa cycloaddition/rearrangement cascade between terminal acetylene 30 derived from acetonide of L-gliceraldehyde, nitrone $2 \mathbf{s}$ and $N, N, N^{\prime}, N^{\prime}$-tetramethylguanidine (TMG). The desired product $\mathbf{3 x}$ was obtained along with two other isomers $23 \mathbf{f}$ and 18k. It should
10 be noted that $\mathbf{3 x}$ and the trans isomer $\mathbf{2 3 f}$ have the same configuration at C4 of the azetidin-2-one ring. Thus, $\mathbf{3 x}$ and $\mathbf{2 3 f}$ can be used for the next steps without separation. It was the first example of an application of the Kinugasa reaction in a targetoriented synthesis (Scheme 17).

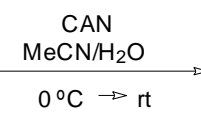<smiles>[CH]C1NC(=O)C1NC(C)(C)C</smiles>

$4 p(86 \%)$<smiles>[O-][N+](=Cc1ccc(OCc2ccccc2)cc1)c1ccc(F)cc1</smiles>

2s

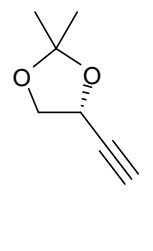

30

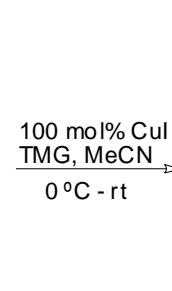

(41\%)<smiles>CC(C)(C)Oc1ccc([C@H]2C(C3COC(C)(C)O3)C(=O)N2c2ccc(F)cc2)cc1</smiles>

$23 f(12 \%)$<smiles>CCCCOc1ccc(C2C(C3COC(C)(C)O3)C(=O)N2c2ccc(F)cc2)cc1</smiles>

$18 \mathrm{k}(5 \%)$<smiles></smiles><smiles>O=C1[C@H](CCC(O)c2ccc(F)cc2)[C@@H](c2ccc(O)cc2)N1c1ccc(F)cc1</smiles>

Scheme 17. Synthesis of cholesterol absorption inhibitor ezetimibe $\mathbf{2 3 h}$.

${ }_{20}$ Based on these results, the same group ${ }^{30}$ studied the reaction of a

series of protected and unprotected chiral propargyl alcohols 3033 and diaryl nitrones 2 to afford azetidin-2-one derivatives 3, 4, 
18 and 23 with a well-defined stereochemistry. The Kinugasa reactions involving $\mathrm{C}, \mathrm{N}$-diaryl imine oxides offered a lower level of stereoselectivity, reflected by the detection of four possible isomeric $\beta$-lactam products although cis adduct $\mathbf{3}$ was the major 5 product. This type of product was obtained in moderate to good diastereoselectivity which could be further modulated by changing the electronic properties of the nitrone 2 . The use of unprotected chiral propargylic alcohols 32a and 33a-b gave $\beta$ lactam derivatives 3, 4, 18 and 23 in good overall yields. 10 Moreover, a mixture of four possible isomers chromatographically inseparable was obtained (Scheme 18).

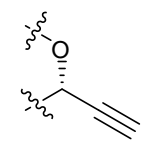

30-33

$$
\underset{-\mathrm{O}_{+}^{-\mathrm{N}}-\mathrm{R}^{2}}{\substack{\mathrm{MeCN}[0.1 \mathrm{M}] \\ \mathrm{rt}, 24 \mathrm{~h}}}
$$

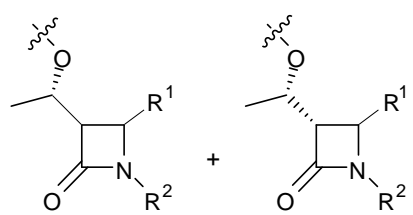

2a $\mathrm{R}^{1}=\mathrm{R}^{2}=\mathrm{Ph}$

2s $\mathrm{R}^{1}=\mathrm{p}-(\mathrm{OBn}) \mathrm{C}_{6} \mathrm{H}_{4}, \mathrm{R}^{2}=\mathrm{p}-\mathrm{FC}_{6} \mathrm{H}_{4}$

2t $\mathrm{R}^{1}=\mathrm{Ph}, \mathrm{R}^{2}=\mathrm{p}-(\mathrm{OBn}) \mathrm{C}_{6} \mathrm{H}_{4}$

2u $\mathrm{R}^{1}=\mathrm{p}-\mathrm{FC}_{6} \mathrm{H}_{4}, \mathrm{R}^{2}=\mathrm{Ph}$

2v $\mathrm{R}^{1}=\mathrm{p}-\mathrm{FC}_{6} \mathrm{H}_{4}, \mathrm{R}^{2}=\mathrm{p}-(\mathrm{OTs}) \mathrm{C}_{6} \mathrm{H}_{4}$

2w $\mathrm{R}^{1}=\mathrm{p}-\mathrm{FC}_{6} \mathrm{H}_{4}, \mathrm{R}^{2}=\mathrm{p}-(\mathrm{OMs}) \mathrm{C}_{6} \mathrm{H}_{4}$
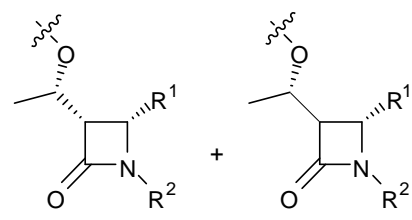

18

$(d r=18: 4>30: 70)$

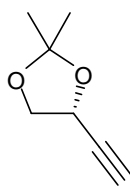

30<smiles>C#C[C@H]1CCOC(C)(C)O1</smiles>

31

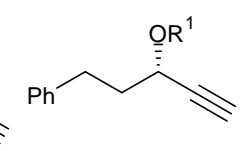

$$
\begin{array}{ll}
\text { 32a } R^{1}=H & \text { 33a } R^{1}=P h, R^{2}=H \\
\text { 32b } R^{1}=T B S & \text { 33 } b R^{1}=M e, R^{2}=H \\
& \text { 33c } R^{1}=P h, R^{2}=T B S
\end{array}
$$

Scheme 18. Kinugasa reaction of chiral acetylenes and diaryl nitrones.

\section{2.1.2.3 Asymmetric Kinugasa reaction using chiral nitrones}

Carbapenems are $\beta$-lactam antibiotics endowed with a broader spectrum, activity and resistance to $\beta$-lactamases than other $\beta$ lactams. The term "carbapenem" is defined as the 4:5 fused ring lactam of penicillins with a double bond between C-2 and C-3 but 20 with the substitution of carbon for sulfur at C-1. On the other hand, carbapenam is a $\beta$-lactam compound that is a saturated carbapenem (Figure 3). These compounds exist primarily as biosynthetic intermediates on the way to the carbapenem antibiotics.

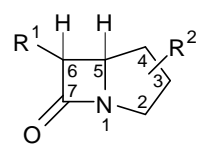

Figure 3. Structure of cis-carbapenam.

A stereoselective synthesis of carpenams via Kinugasa reaction between terminal copper acetylides and nonracemic cyclic nitrones derived from malic and tartaric acid was reported by ${ }_{30}$ Chmielewski. ${ }^{31}$ The reaction of nitrone $\mathbf{3 4}$ with phenylacetylene 6a gave two bicyclic products 35a and 36a in a ratio of 85:15 and $56 \%$ yield. The use of other acetylenes $\mathbf{6 e - g}$ provided products with high diastereoselectivity but rather a poor yield. In all cases, the anti approach to the t-BuO was observed and the 5,6-cis35 penams 35 were obtained as a major component (Scheme 19).
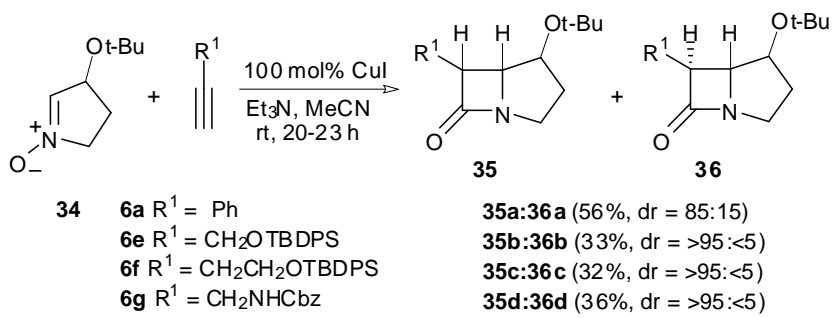

Scheme 19. Diastereoselective synthesis of Carbapenams via Kinugasa reaction.

40 The stereochemical outcome of the Kinugasa reaction is controlled by the initial cycloaddition step leading to the isoxazoline intermediate. The cycloaddition step determines the configuration at the bridgehead carbon atom. Two possible approaches of acetylides to the nitrone are shown in figure 4 . The 45 approach of acetylide to the si side of the nitrones (syn to t-BuO) is disfavoured due to the steric interactions. The lack of steric hindrance for the nitrones re side makes approach of the acetylide more favourable. The cis substitution of $\beta$-lactam ring is observed either exclusively, or it significantly dominates since the 50 protonation of the copper enolate proceeds from the less shielded convex-side of the carbapenam skeleton. The subsequent generation of the stereogenic center at C-6 depends on the configuration at previously created bridgehead carbon atom C-5 and proceeds through a protonation of the intermediate enolate 55 (resulting by rearrangement of the isoxazoline) from its convex or concave side.
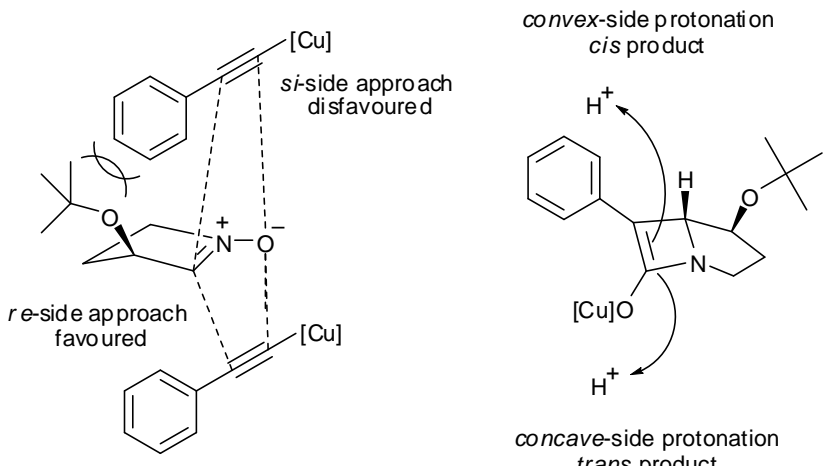

concave-side protonation trans product

Figure 4. Stereochemical course of the Kinugasa reaction as proposed by 60 Chmielewski.

In 2009, the same group $^{32}$ described a Kinugasa reaction involving nonracemic cyclic nitrones 34, 37-39 and chiral, optically pure acetylenes $\mathbf{4 0 - 4 3}$. The reactions displayed high diastereoselectivity affording the cis dominant product 35e, 44 65 and 45. The yields of desired products vary from poor, for 
aliphatic acetylenes, to moderate and good for aryl acetylenes. The configuration of the nitrone controlled the 1,3-dipolar cycloaddition step when acetylene and nitrone are chiral. By the other side, the geometry of the acetylene component can 5 influence direction of asymmetric induction only if the nitrone is not chiral. In all cases, the major products exhibit the relative cis orientation of protons in the four-membered $\beta$-lactam ring (Scheme 20).<smiles>CCCC[C@H]1C=[N+]([O-])CC1</smiles>

$\mathrm{O}_{-}$ 34<smiles>[R][C@H](C)C#C</smiles>

40a $\mathrm{R}^{1}=\mathrm{Bn}$ 40b $\mathrm{R}^{1}=\mathrm{SiPh}_{2} \mathrm{t}-\mathrm{Bu}$

10

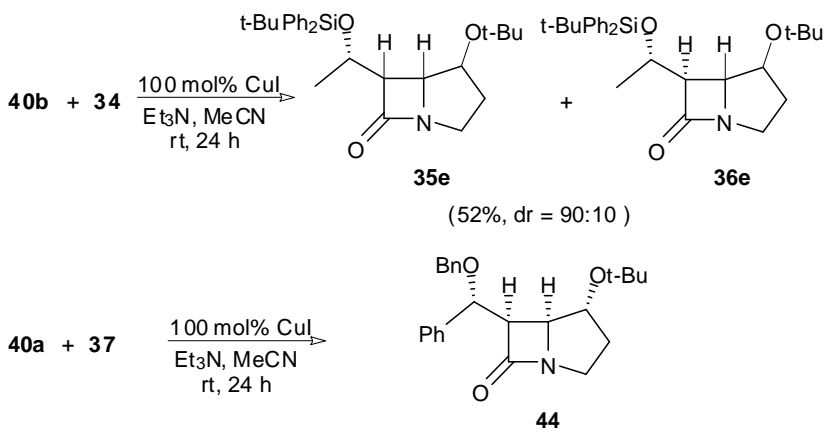

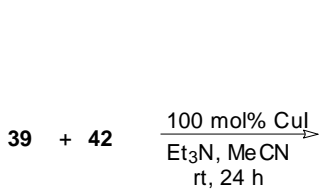

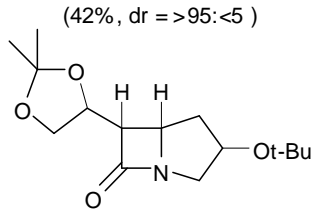

45

$(45 \%, d r=>95:<5)$

Scheme 20. Kinugasa reaction between chiral acetylenes and chiral nitrones.

15 In another reports, Chmielewski ${ }^{15,33}$ described that acetylenes derived from D-glyceraldehyde acetonide 42 and propargyl adehyde 46 displayed a remarkable reactivity in the Kinugasa reaction (Scheme 21). This is due to the formation of the highly reactive rigid dinuclear copper(I) complex (Figure 5) in which 20 copper ion is coordinated to one or both oxygen atoms in the acetylene molecule and to both triple bonds. The rigid structure of the dioxolane stabilizes the conformation of the acetylide and enables an optimal interaction of oxygen atoms with the copper ion. It should be noted that two nucleophilic centers are necessary 25 for the effective coordination of the copper ion, and thus to activate the triple bond for the cycloaddition reaction with nitrones. The high active acetylenes afforded the best results in the presence of catalytic amounts of the copper salt. However, less-reactive acetylenes require a long reaction time which
30 promotes side process. In these studies, the effectiveness of acetylene in the Kinugasa reaction can be improved by the addition of 1,10-phenantroline.

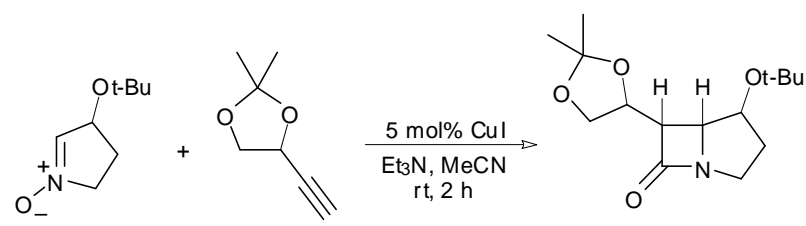

$$
34 \quad 42 \quad 35 f(80 \%)
$$

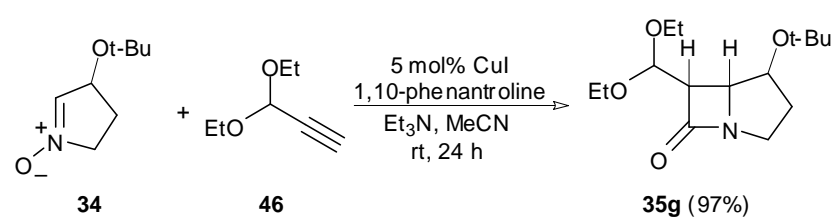

35 Scheme 21. Carbapenams via cycloaddition reaction.
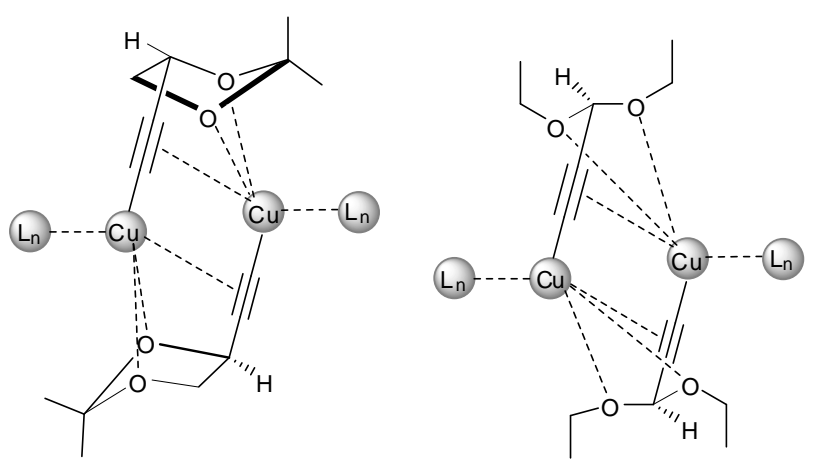

Ln: all nucleophilic ligands or reagents involved in the coordination sphere of the copper ion (nitrones oxygen atom, halogen atom, 1,10-phenantroline, $\left.\mathrm{Et}_{3} \mathrm{~N}, \mathrm{MeCN}\right)$.

Figure 5. Plausible coordination of copper(I) complexes formed from acetylenes $\mathbf{4 2}$ and $\mathbf{4 6 .}$

The synthesis of a variety of chiral $\beta$-lactams by the Kinugasa 40 reactions between cyclic nitrones 47-50 and sugar-derived acetylenes 51-55 were achieved by Kaliappan. ${ }^{34}$ This author suggests that the addition of a sugar unit to both templates has a significant effect in improving the bioavailability of these $\beta$ lactams. The reaction was carried out with 3 equiv. of CuI, ${ }_{45}$ dicyclohexylamine in dry $\mathrm{MeCN}$ at $0{ }^{\circ} \mathrm{C}$ and under these reaction conditions, the cis $\beta$-lactams $\mathbf{5 6 - 6 0}$ were obtained in good to excellent yields as sole products (Scheme 22). However in some cases, the authors observed the Glaser coupling product (dimer of alkynes) as a minor side product.

50 Subsequently, Chmielewski ${ }^{33}$ described an application of Kinugasa reaction from sugar-derived cyclic nitrones 47, 48, 6164 and simple non chiral and chiral acetylenes 65-70 (Scheme 23). The reaction proceeded in moderate to good yields and displayed high levels of diastereoselectivity affording mostly one 55 predominant cis-product 71a or $\mathbf{7 1 b}$. Interesting double addition was observed in the case of diyne $\mathbf{7 0}$ derived from D-tartaric acid (Scheme 24). The bis-substituted product 72 was formed with high stereoselectivity via reaction of two of the same matched pair. 


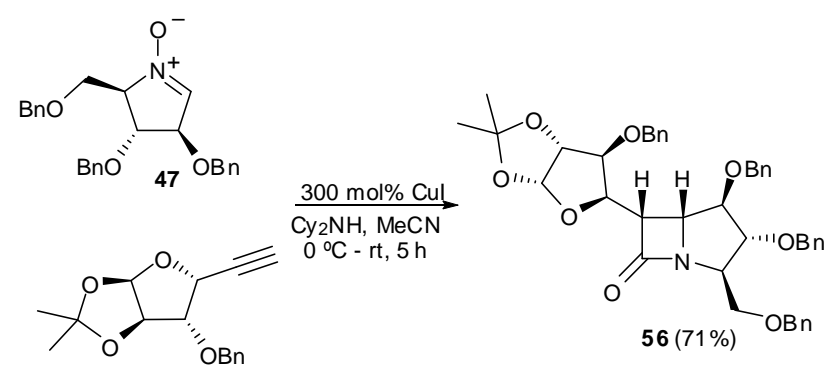

51<smiles>[O-][N+]1=C[C@@H](Br)[C@H](COCc2ccccc2)[C@@H]1Br</smiles><smiles>C#C[C@H]1O[C@@H]2OC(C)(C)O[C@@H]2[C@H]2OC(C)(C)O[C@@H]21</smiles>

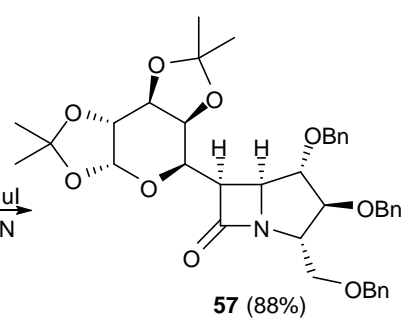<smiles>[O-][C@H]1C=[N+]([O-])[C@@H](COCc2ccccc2)[C@@H]1Br</smiles><smiles>C#C[C@H]1OC[C@@H]2OC(C)(C)O[C@@H]21</smiles>

$\frac{300 \mathrm{~mol} \% \mathrm{Cul}}{\mathrm{Cy}{ }_{2} \mathrm{NH}, \mathrm{MeCN}}$ $0^{\circ} \mathrm{C}-\mathrm{rt}, 5 \mathrm{~h}$

53<smiles>O=C(O[C@H]1[C@@H](OCc2ccccc2)C=[N+]([O-])[C@H]1Br)c1ccccc1</smiles><smiles>C#C[C@H]1O[C@@H](OC)[C@H]2OC(C)(C)O[C@@H]21</smiles>

54<smiles>[O-][N+]1=C[C@@H](OC(Br)(Br)c2ccccc2)[C@H](Br)C1</smiles><smiles>C#C[C@H]1OC(OC)[C@H]2OC(C)(C)O[C@@H]21</smiles>

55

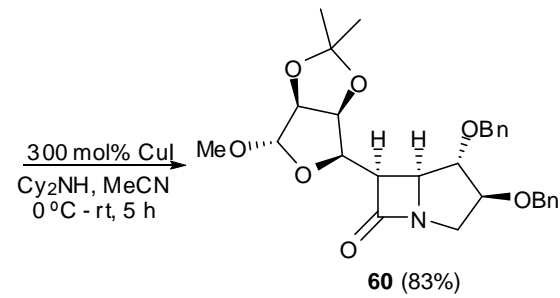

Scheme 22. Kinugasa reaction between cyclic nitrones and sugar-derived acetylenes.

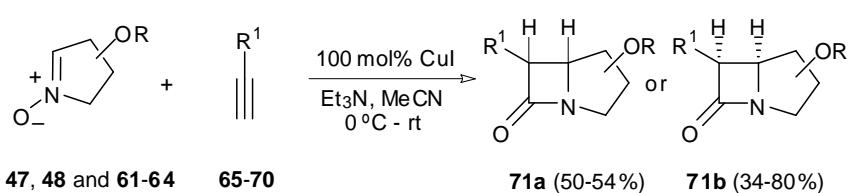<smiles>[O-][N+]1=CC([18O]c2ccccc2)[C@H](OCc2ccccc2)C1CBr</smiles><smiles>[O-][N+]1=C[C@@H](OCc2ccccc2)C(O)[C@H]1COCc1ccccc1</smiles><smiles>[O-][N+]1=CC(OCBr)[C@H](COCc2ccccc2)[C@@H]1Br</smiles>

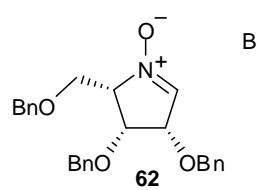<smiles>[O-][N+]1=CC[C@@H](OCc2ccccc2)[C@@H]1Cc1ccccc1</smiles><smiles>CC1(C)CC2C=[N+]([O-])[C@H](C3COC(C)(C)O3)C2C1</smiles><smiles>C#CC[18OH]</smiles>

65<smiles>C#CC(=O)C#CC(=C)C</smiles>

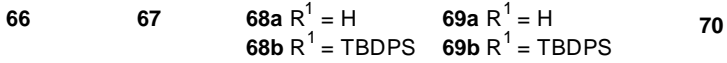

Scheme 23. Kinugasa reaction involving sugar-derived cyclic nitrones and different acetylenes.

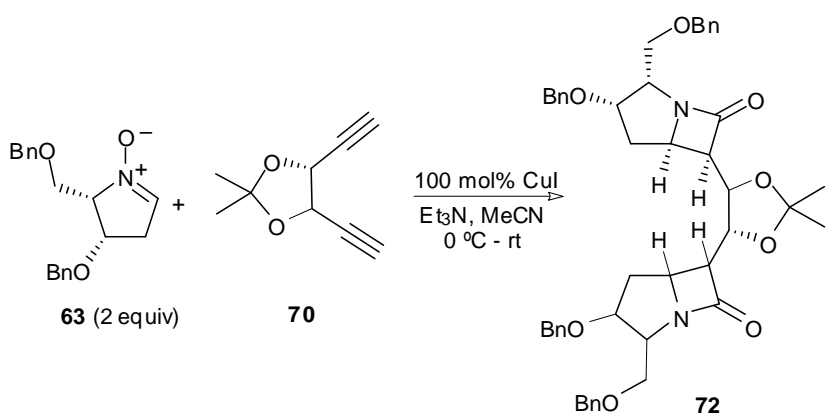

10 Scheme 24. Chmielewski's synthesis of bis-substituted product 72 via Kinugasa reaction.

Kinugasa reaction between terminal acetylenes $\mathbf{6 a}$ or $\mathbf{4 2}$ and six-membered ring nitrone $\mathbf{7 3}$ proceeded in a low to moderate yield and high diastereoselectivity affording dominant cis $\beta$ 15 lactam products 74a-b (Scheme 25). ${ }^{35}$ In this reaction, the configuration of the nitrones controlled the 1,3-dipolar cycloaddition (first step). The protonation of the intermediate enolate in the second step depends on a) the configuration of the bridgehead carbon atom formed in the first step, b) epimerization 20 process in the presence of a base, and c) the configuration of the stereogenic center in the acetylenic partner. 
<smiles>C#CC(=O)c1ccccc1</smiles>

73

$6 a$<smiles>[O-][N+]1=CC(OCc2ccccc2)CCC1</smiles>

73

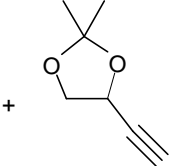

42
$\underset{\mathrm{Et} \mathrm{m}_{3} \mathrm{~N}, \mathrm{MeCN}}{\mathrm{O} \mathrm{Cul}}$<smiles>O=C1[C@H](c2ccccc2)[C@@H]2[C@H](OCc3ccccc3)CCCN12</smiles>

$74 a(65 \%)$

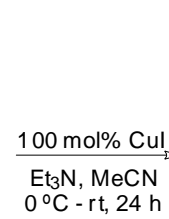<smiles>CCCCC1CCCN2C(=O)[C@@H](C3COC(C)(C)O3)C12</smiles>

$74 \mathrm{~b}(45 \%, \mathrm{dr}=2: 1)$
Scheme 25. Asymmetric Kinugasa reaction involving six-membered 5 cyclic nitrones.

\subsubsection{Intramolecular Kinugasa reaction}

$\beta$-Lactam-fused enediynes has gained importance because of the ability of the $\beta$-lactam-ring to act as a molecular clock in stabilizing the otherwise unstable enedyne moiety. ${ }^{36}$ The 10 formation of enediyne involves important steps like the construction of the acyclic enediyne framework by Sonogashira coupling, $O$-propargylation, functional group modification to generate the nitrones and an intramolecular Kinugasa reaction. The precursor 75 was synthesized in 10 steps, but when this 15 nitrone was subjected to the Kinugasa reactions conditions, two different $\beta$-lactams were isolated. The trans fused system $\mathbf{7 6}$ and the dehydration product 77 (Scheme 26).

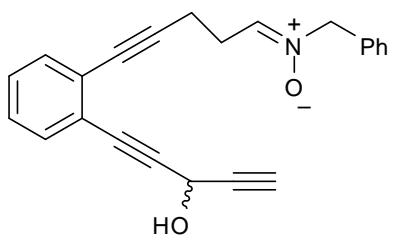

75

$\downarrow$ Cul, Et3N, MeCN

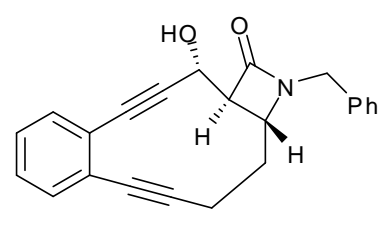

76

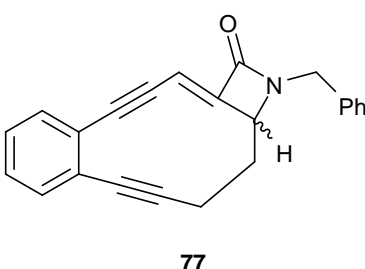

77

$$
76: 77(65 \%, d r=4: 1)
$$

Scheme 26. Synthesis of enediynes by an intramolecular Kinugasa 20 reaction.

As shown in Scheme 8, the research group of Fu established that a $\mathrm{Cu} /$ phosphaferrocene-oxazoline catalyst promotes an intermolecular Kinugasa reaction for preparing monocyclic $\beta$ lactams with excellent diastereoselectivity and good ees. Based 25 on these results, $\mathrm{Fu}^{37}$ have demonstrated that an intramolecular Kinugasa reaction can be used to prepare fused tricyclic compounds containing a 6,4 or a 7,4 ring systems $\mathbf{8 0}$ (Scheme 27). The reaction was carried out in the presence of a planar- chiral $\mathrm{Cu}$ /phosphaferrocene-oxazoline catalyst 79 and produced so two new rings efficiently with very good levels of enantioselectivity.

Scheme 27. Intramolecular Kinugasa reactions in the presence of planarchiral phosphaferrocene-oxazoline ligands.

35 The copper enolate intermediate $\mathbf{B}$ postulated in the mechanism of the Kinugasa reaction (Scheme 4) could be intercepted when an electrophile is added to the reaction mixture. For this reason, allyl iodide $\mathbf{8 1}$ was used as electrophile in the presence of a mixture of a silyl enol ether and KOAc as the base 40 (Scheme 28). The heterocyclic substrate $\mathbf{7 8 d}$ was efficiently converted into the desired enantioenriched $\beta$-lactam 82 (90\% ee and $70 \%$ yield) Thus, two carbon-carbon bonds, a carbonnitrogen bond, two new rings (including a $\beta$-lactam), a carbonyl group, and adjacent tertiary and quaternary stereocenters could be 45 generated in a single cyclization-alkylation sequence.

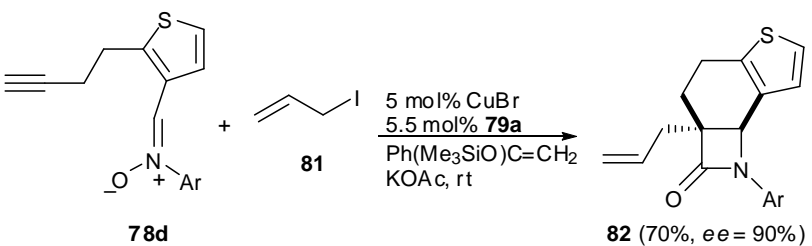

Ar $=p$-carboethoxyphenyl

Scheme 28. Synthesis of enantio-enriched tricyclic $\beta$-lactam using an intramolecular Kinugasa reaction.

Jørgensen and col. ${ }^{38}$ have developed a Michael 50 addition/cycloaddition based one-pot protocol for the highly enantio- and diastereoselective syntheses of $\beta$-lactams 87a-e (Scheme 29). The reaction was achieved in the presence of malononitrile derivatives $\mathbf{8 3}$, aliphatic $\alpha, \beta$-unsaturated aldehydes 84a-e, and catalyst 85 in order to obtain a Michael adduct. The 
subsequent addition of $\mathrm{N}$-phenylhydroxylamine and $\mathrm{CuI}$ afforded the corresponding $\beta$-lactams $\mathbf{8 7}$ in good yields. In the formation of $(E)-\mathbf{8 7 d}$ and $(Z)-87 \mathbf{e}$, no competing side reaction with the alkene moiety was observed, even though these compounds are 5 ideally positioned to form a six-membered ring in general favored

10 over the alkyne to act as acceptor in 1,3-dipolar cycloadditions.

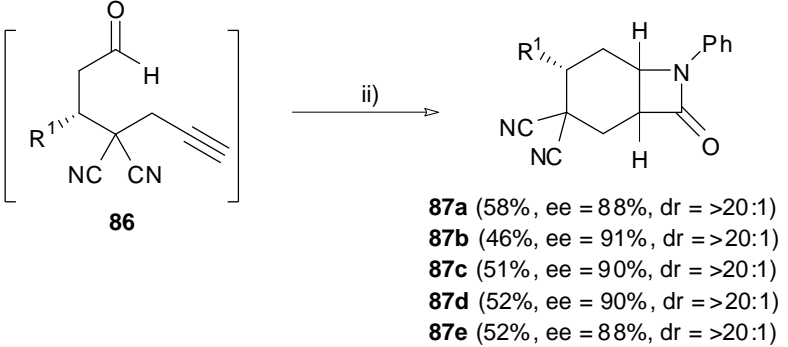

i) $10 \mathrm{~mol} \% 85,10 \mathrm{~mol} \% \mathrm{PhCO}_{2} \mathrm{H}, \mathrm{CH}_{2} \mathrm{Cl}_{2}, \mathrm{rt}, 24 \mathrm{~h}$. ii) $\mathrm{PhNHOH}, \mathrm{CH}_{2} \mathrm{Cl}_{2}, 0^{\circ} \mathrm{C}, 1 \mathrm{~h}$; then: 25 mol\% Cul, 1,10-phenantroline, Et $3 \mathrm{~N}$, rt, $24 \mathrm{~h}$.

Scheme 29. Enantio- and diastereoselective syntheses of $\beta$-lactams from a Michael addition/cycloaddition and Kinugasa reaction sequence.

The proposed reaction course to explain formation of compounds 87 (Scheme 30) starts when the Michael adduct 86 15 condenses with $N$-phenylhydroxylamine to form nitrone $\mathbf{8 8}$. This copper acetylide nitrone $\mathbf{8 8}$ undergoes intramolecular 1,3-dipolar cycloaddition to form the vinyl cuprate 89. This collapses to ketene 90, which, after aniline addition/tautomerization, affords $\beta$-lactams 87.

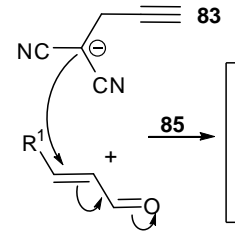

84<smiles>[R7]C(CC=O)C(C#N)(C#N)CC#CCC</smiles>

86
88

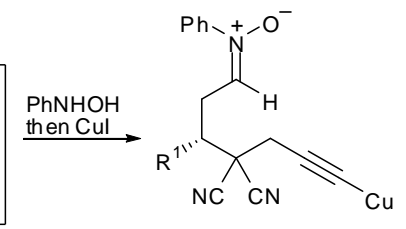

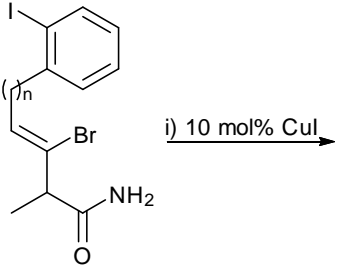

91a $n=1$ 91b $n=2$

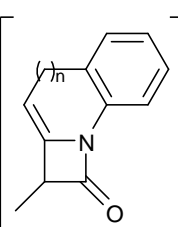

$92 a$<smiles>CC1C(=O)CCCCC1Nc1ccccc1Cl</smiles>

93a $(90 \%)$ 93b $(99 \%)$ i) $10 \mathrm{~mol} \% \mathrm{Cul}, 20 \mathrm{~mol} \% \mathrm{DMG} \cdot \mathrm{HCl}, \mathrm{K}_{2} \mathrm{CO}_{3}, \mathrm{MeCN}, \Delta, 12 \mathrm{~h}$.

35

Scheme 31. Medium-sized lactams 93 via tandem C-N bond formation.

\subsection{Synthesis of $\beta$-lactams via an oxidative process}

Zhang and col. $^{40}$ have established, for the first time, the catalytic conditions for the synthesis of $\beta$-keto- $\beta$-lactams 95 40 bearing a double spirocyclic structure by an oxidative coupling process (Scheme 32). Treatment of the amides 94 with catalytic amount of copper sulfate pentahydrate and DMAP in absolute ethanol led to the formation of lactams 95a-f. The synthesis of highly functional and rigid double spirocyclic $\beta$-lactams by 45 formation of two consecutive quaternary carbon centers concurrently has been achieved in high yield (80-93\%).

\subsection{Synthesis of $\beta$-lactams from Ullman-type coupling}

4-Alkylidene-2-azetidinones 93 (medium-sized lactams) have 25 been synthesized by the $\mathrm{Cu}(\mathrm{I})$-catalyzed intramolecular $\mathrm{C}-\mathrm{N}$ coupling of amides with vinyl bromides. ${ }^{39}$ Reaction of primary amides 91 followed by subsequent hydrolysis with aqueous hydrochloric acid led to the efficient synthesis of 8- or 9membered lactams 93 (Scheme 31). Presumably amides 91 30 underwent 4-exo cyclization followed by intramolecular $\mathrm{N}$ arylation to give the unstable tricyclic intermediates 92 . The hydrolytic cleavage of the enamide $\mathrm{C}-\mathrm{N}$ bond afforded the ring expansion products 93. 

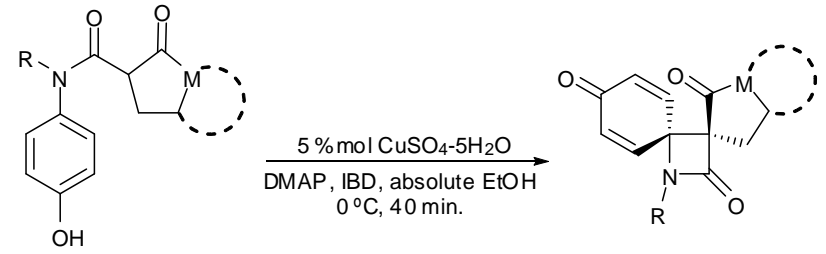

94<smiles>CC(C)CN1C(=O)[C@]2(CCCC2=O)C12C=CC(=O)C=C2</smiles>

$95 \mathrm{a}(82 \%)$
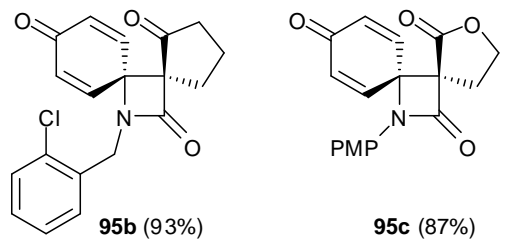

95c (87\%)

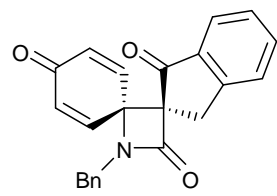

95d (90\%)

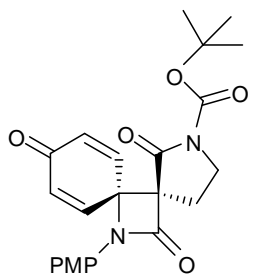

95e (84\%)

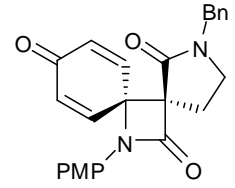

$95 f(80 \%)$

Scheme 32. Copper-catalyzed synthesis of spirocyclic $\beta$-lactams.

\section{Synthesis of azetidine derivatives}

Azetidines are an important class of aza-heterocyclic 5 compounds with remarkable biological activities, which makes them an interesting synthetic topic. ${ }^{41}$ This kind of structure is the smallest nitrogen-containing saturated heterocycle possessing reasonable chemical stability. Moreover, the azetidine ring finds a wide application as a pharmacological tool in many drugs or 10 bioactive compounds, usually in medicinal chemistry.

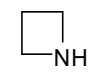

$$
\text { azetidine }
$$

Figure 6. Structure of azetidine.

\subsection{Synthesis of alkylidene azetidines}

$\mathrm{N}$-Tosyl-3-halo-3-butenylamines $\mathbf{9 6}$ have been transformed 15 into 2-alkylideneazetidines $\mathbf{9 7}$ using an efficient Ullman-type coupling with a mixture of $\mathrm{CuI}$ as catalyst and $\mathrm{N}, \mathrm{N}$ dimethylethylendiamine (DMDEA) as ligand. ${ }^{42}$ The cyclization afforded the azetidines in good yields and demonstrated the high efficiency of the four-membered ring closure. The subsequent 20 transformation of compounds $\mathbf{9 7}$ into the corresponding $\beta$ lactams 98a-f was realized through a conventional $\mathrm{O}_{3}$ oxidation procedure (Scheme 33).

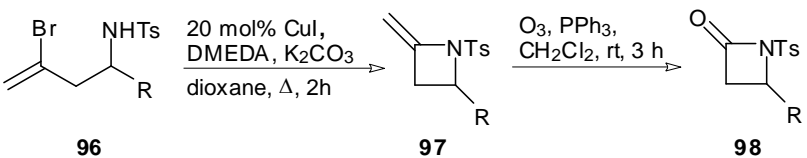

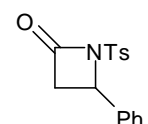

98a (85\%)

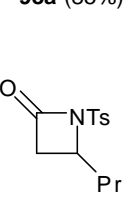

98d (91\%)

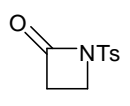

98b (76\%)

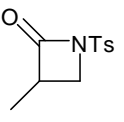

98e $(76 \%)$

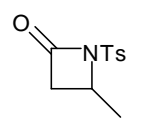

$98 \mathrm{c}(71 \%)$

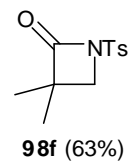

Scheme 33. Synthesis of $\beta$-lactams 98 via alkylideneazetidines 97.

25 In 2003, Akiyama and col. $^{43}$ have studied the catalytic enantioselective [2+2] cycloaddition reaction of $\alpha$-imino esters 99 and 1-methoxyallenes $\mathbf{1 0 0}$ catalyzed by a $\mathrm{Cu}(\mathrm{I})$ complex (Scheme 34). Treatment of 99 and 100 with 10 mol\% (R)-TolBINAP catalyst, THF, molecular sieves $(4 \AA)$ at $-78{ }^{\circ} \mathrm{C}$ gave the 30 cycloadducts 101 with high enantioselectivity. Acid treatment of compounds 101 furnished $\alpha, \beta$-unsaturated- $\beta$-amino-acylsilanes 102. The use of an allenylsilane moiety and the silyl group is essential in order to achieve the cycloaddition reaction.
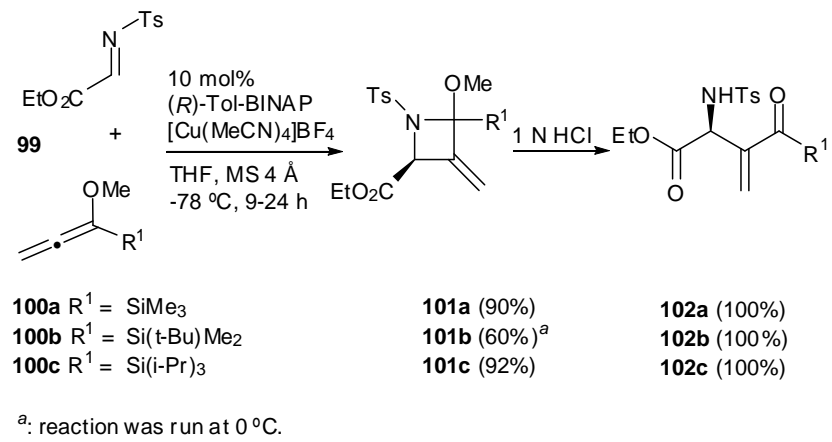

a: reaction was run at $0^{\circ} \mathrm{C}$

35 Scheme 34. Preparation of $\alpha$ - $\beta$-unsaturated- $\beta$-amino-acylsilanes.

\subsection{Synthesis of azetidin-3-ones}

The combination of $\mathrm{N}$-tosyldiazoketone with $\mathrm{Cu}(\mathrm{acac})_{2}$ catalyst provided the cis-substituted azetidine 104. The key step was based on a copper carbenoid $N-\mathrm{H}$ insertion $^{44}$ of $\alpha, \alpha^{\prime}$ 40 dialkyl- $\alpha$-diazoketone $\mathbf{1 0 3}$ to furnish cis-2,4-dialkyl-azetidin-3one $\mathbf{1 0 4}$ as a single diastereoisomer. ${ }^{45}$ The same methodology was applied in the synthesis of cis conformationally constrained glutamate analogue $\mathbf{1 0 7}$ containing an azetidine framework. ${ }^{46}$ The preparation of chiral azetidin-3-one $\mathbf{1 0 6}$ involves the reaction 45 of the diazoketone $\mathbf{1 0 5}$ with $\mathrm{Cu}(\mathrm{acac})_{2}$ in refluxing benzene for promoting the $\mathrm{N}-\mathrm{H}$ insertion reaction in $55 \%$ yield (Scheme 35 ). 


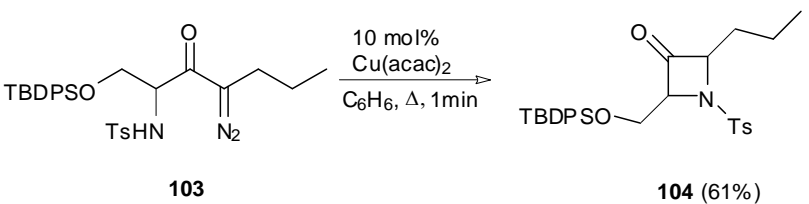<smiles>C#CN1CC(=O)[C@H]1c1ccccc1</smiles>
105 $106(55 \%)$

$107(91 \%)$

Scheme 35. Cu-catalyzed synthesis of azetidin-3-ones 104 and 106.

\subsection{Synthesis of $N$-sulfonylazetidin-2-imines}

It has been shown that sulfonyl azetidinimine products can be 5 viewed as $\beta$-lactam analogues, due to their potential applications as therapeutic agents. The stereoselective conversion of alkynes to $\mathrm{N}$-sulfonylazetidin-2-imines $\mathbf{1 1 0}$ by the initial reaction of copper(I) acetylides with sulfonyl azides 108, followed, in situ, by formal [2+2] cycloaddition was reported by Fokin and col. ${ }^{47}$ ${ }_{10}$ This group of research examined the MCR (multicomponent reaction) of different acetylenes $\mathbf{6 a}, \mathbf{6 h}$, sulfonyl azides $108 \mathbf{a}$ and $\mathbf{1 0 8 b}$ in the presence of $N$-benzylideneanilines 109a and 109b as nucleophiles. This reaction revealed, that both alkyl and aryl alkynes gave the expected azetidinimine 110a-c with high trans 15 selectivity. The reaction appears to be amenable to the use of a wide range of sulfonyl azides 108, alkynes 6 and imines 109 (Scheme 36). This three-component coupling proceed through the initial reaction of in situ generated copper(I) acetylides with sulfonyl azides $\mathbf{1 0 8}$ to give transient (1-sulfonyltriazolyl)copper 20 intermediates which, upon extrusion of molecular nitrogen, generate $N$-sulfonylketenimines 110a-c.

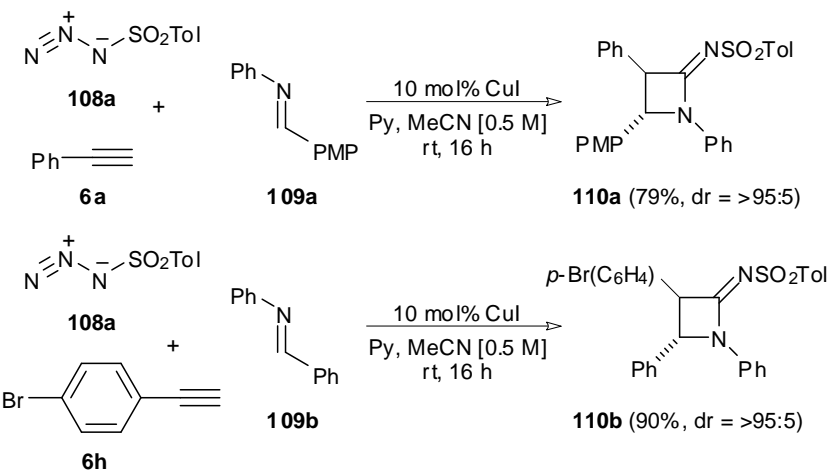

$$
\text { 108b } \mathrm{R}_{1}=p\left(\mathrm{NO}_{2}\right)-\mathrm{C}_{6} \mathrm{H}_{4}
$$

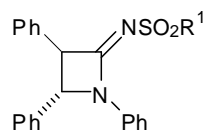

$6 a$

Scheme 36. Stereoselective synthesis of $N$-sulfonylazetidin-2-imines $\mathbf{1 1 0}$.

25 Recently, the ketenimine intermediate $\mathbf{1 1 1}^{\mathbf{4 8}}$ generated in the copper catalyzed azide-alkyne cycloaddition has been trapped by tetramethylguanidine $\mathbf{1 1 2}$ as nucleophile in order to achieve the corresponding derivative $\mathbf{1 1 3}$ in 80\% yield (Scheme 37).

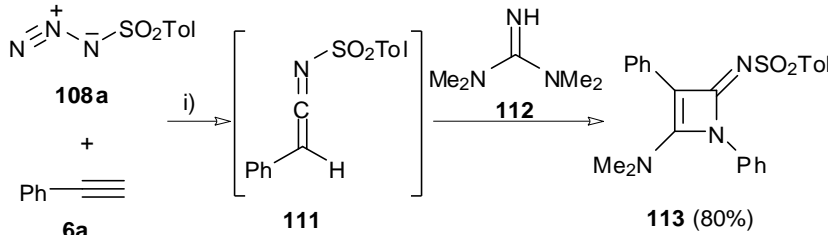

i) $10 \mathrm{~mol} \% \mathrm{Cul}, \mathrm{Et}_{3} \mathrm{~N}, \mathrm{THF}, \mathrm{rt}, 12 \mathrm{~h}$.

${ }_{30}$ Scheme 37. Synthesis of functionalized 1,4-dihidroazete derivative.

Synthesis of a collection of 2-(sulfonylimino)-4(alkylimino)azetidine derivatives 115 via a copper-catalyzed multicomponent reaction of readily available terminal alkynes $\mathbf{6}$, 35 sulfonyl azide 108a, and carbodiimide without the assistance of a base has been accomplished (Scheme 38). ${ }^{49}$ The desired 2(sulfonylimino)-4-(alkylimino)azetidines $\mathbf{1 1 5}$ were isolated in 71$94 \%$ yield. In the presence of DCC or DIC and CuI, alkyne 5 reacts with sulfonyl azide $\mathbf{1 0 8}$ through two possible pathways to 40 form the ketenimine species $\mathbf{1 1 7}$ according to Chang $^{50}$ and Fokin's proposal, ${ }^{47}$ in which DCC or DIC could act as a weak base. Protonation of $\mathbf{1 1 7}$ gives rise to the highly reactive ketenimine 118 and regenerates the copper catalyst. Then, 118 reacts with carbodiimide 114 through a [2 +2] cycloaddition to 45 afford the desired product $\mathbf{1 1 5}$ (Scheme 39).

$$
\begin{aligned}
& \mathrm{N}^{\mathrm{N}} \stackrel{+}{\mathrm{N}}-\mathrm{SO}_{2} \mathrm{Tol} \\
& \mathrm{R}^{1 \rightleftharpoons}=\mathrm{R}^{2}-\mathrm{N}=\mathrm{C}=\mathrm{N}-\mathrm{R}^{2} \stackrel{10 \mathrm{~mol} \% \mathrm{Cul}}{\mathrm{MeCN}, \mathrm{rt}, 16 \mathrm{~h}} \\
& \begin{array}{ll}
6 a R^{1}=P h & 115 a(94 \%) \\
6 c R^{1}=p-(\mathrm{MeO}) \mathrm{C}_{6} \mathrm{H}_{4} & 115 b(87 \%)
\end{array} \\
& \text { 6i } \mathrm{R}^{1}=\mathrm{CH}_{3}\left(\mathrm{CH}_{2}\right)_{3} \quad \text { 115c }(65 \%)
\end{aligned}
$$

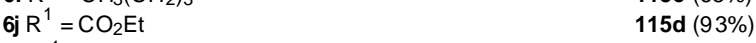

$$
\begin{aligned}
& 6 \mathbf{R ~ R}^{1}=\mathrm{CH}_{3}\left(\mathrm{CH}_{2}\right)_{4} \quad \text { 115e (71\%) }
\end{aligned}
$$

Scheme 38. Synthesis of 2-(sulfonylimino)-4-(alkylimino)azetidine derivatives 115.

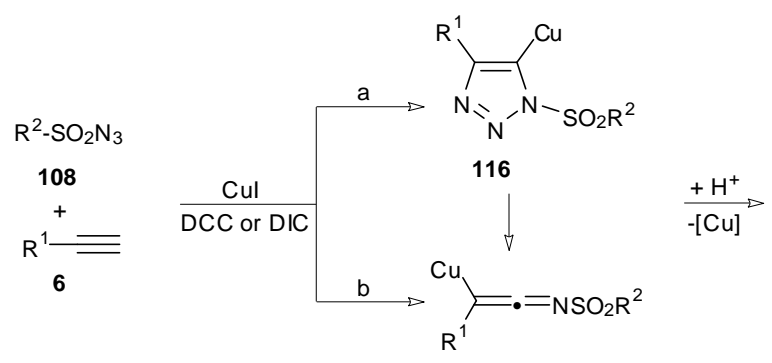

$$
\stackrel{\mathrm{H}}{=}=\mathrm{R}^{1}=\mathrm{NSO}_{2} \mathrm{R}^{2} \quad \stackrel{\mathrm{R}^{3}-\mathrm{N}=\mathrm{C}=\mathrm{N}-\mathrm{R}^{3}}{\mathbf{1 1 4 a}}
$$

50

$$
118
$$

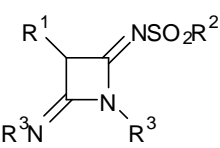

115
Scheme 39. Proposed mechanism for the formation of $N$-sulfonylazetidin2-imines as proposed by $\mathrm{Xu}$.

The groups of Fokin and $\mathrm{Xu}$ have reported copper(I)iodide catalyzed MCRs. However, these processes either proceeded in 55 organic solvents in the presence of ligands or bases. In addition to the above-mentioned synthesis of azetidines, there is a different 
three-component reaction that has been achieved using $10 \mathrm{~mol} \%$ of copper(I)oxide $\left(\mathrm{Cu}_{2} \mathrm{O}\right)$ and solvent-free conditions. ${ }^{51}$ When the reactions were carried out at room temperature, the $\mathrm{N}$ sulfonylazetidin-2-imines $\mathbf{1 1 5}$ were prepared in good yields and 5 the reaction system confirms that the addition of a base as promoter is not required (Scheme 40).

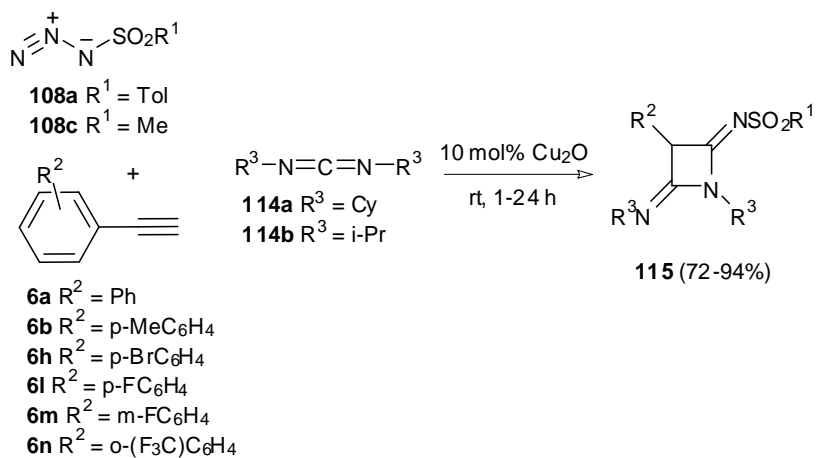

Scheme 40. MCR catalyzed by copper(I)oxide $\left(\mathrm{Cu}_{2} \mathrm{O}\right)$.

Very recently, Wang and co-workers have reported ${ }^{52}$ a $\mathrm{Cu}-$ 10 catalyzed four-component reaction of imidoyl chlorides 119, sulfonyl azides 108, and terminal alkynes $\mathbf{6}$, which afforded polyfunctionalized azetidin-2-imines $\mathbf{1 2 0}$ in good to excellent yield with high diastereoselectivity. This methodology supported different aryl alkynes, aryl or alkyl sulfonyl azides and different 15 imidoyl chlorides derived from $N$-benzyl amides. In the Scheme 41 is shown only the optimized preparation of azetidin-2-imine 120a from mixed alkynes. The product showed two aryl groups in the azetidin-2-imine rings in cis configuration, because of the cis-adducts were the thermodynamically favored products in this 20 MCR. The synthesized azetidin-2-imines 120b-e were converted into dihydroazeto[1,2- $\alpha$ ]benzo[e]azepin-2(4H)-imines 122b-e via an electrophilic cyclization using $\mathrm{H}_{2} \mathrm{SO}_{4}$ in DCE (Scheme 41).
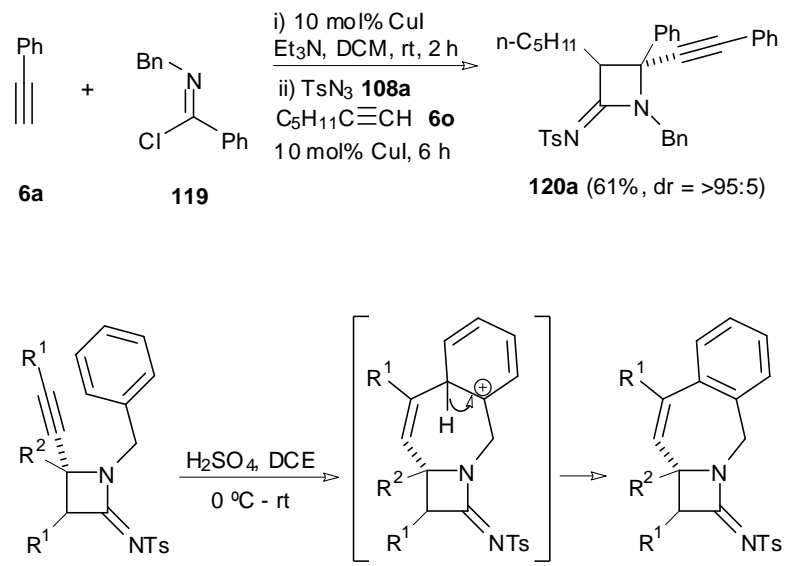

$$
\begin{aligned}
& \text { 120b } R^{1}=R^{2}=P h \\
& \text { 120c } R^{1}=p-B^{2} C_{6} H_{4}, R^{2}=P h \\
& \text { 120d } R^{1}=P h, R^{2}=0-B^{2} C_{6} H_{4}
\end{aligned}
$$$$
121
$$$$
\text { 122b }(78 \%)
$$$$
\text { 122c (81\%) }
$$$$
\text { 122d (67\%) }
$$

120e R $R^{1}=P h, R^{2}=p-B r C_{6} H_{4}$

Scheme 41. Preparation of azetidin-2-imines $\mathbf{1 2 0}$ and 122.

25 The possible mechanism is shown in Scheme 42. In the presence of a base, the copper-catalyzed Csp-Csp ${ }^{2}$ coupling reaction between terminal alkyne $\mathbf{6 a}$ and imidoyl chloride $\mathbf{1 1 9}$ forms the ynimine intermediate 123. Meanwhile, the copper-

catalyzed alkyne-azide cycloaddition occurs to form the 30 ketenimine intermediate 111. Subsequently, a [2+2] cycloaddition between 123 and $\mathbf{1 1 1}$ takes place to furnish azetidin-2-imine $\mathbf{1 2 0}$. The remarkable diastereoselectivity for the formation of cis-120b can be attributed due to the thermodynamic stability of the cisproduct.

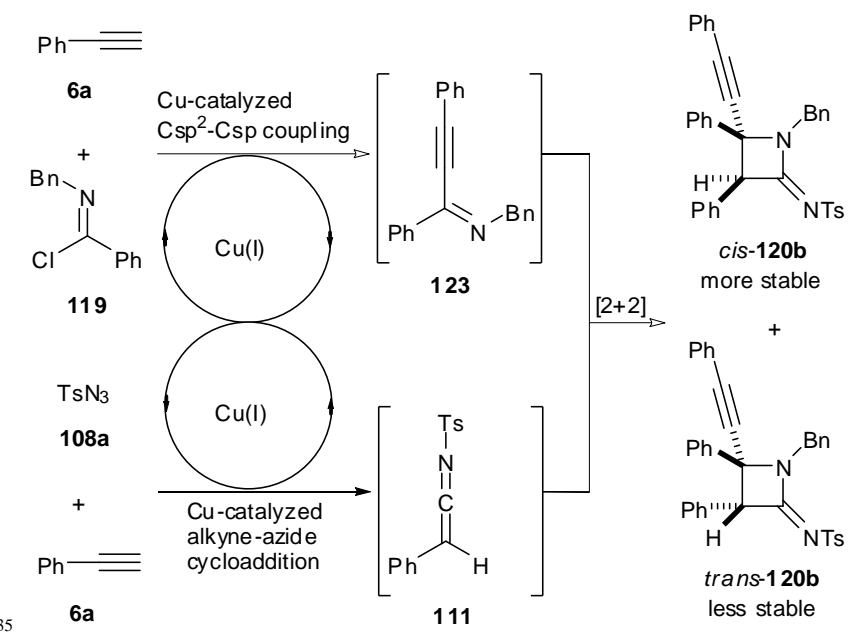

Scheme 42. Plausible mechanism for the formation of azetidin-2-imines 120.

A new-one pot procedure for obtaining ferrocenyl 40 azetidinimines from ferrocenylimines was developed (Scheme 43). ${ }^{53}$ Reaction of compounds 124a-e with $p$-toluenesulfonyl azide 108a, alkyne $\mathbf{6 a}$ and catalytic (10 mol\%) amount of $\mathrm{CuI}$ in acetonitrile gave the corresponding nitrogen heterocyclic substituted rigid ferrocenyl azetidinimines 125a-e in good yield. 45 Electron releasing and withdrawing groups at 3- and 4- positions of the benzene ring of ferrocenyl imines 124 were proved Electron rich ferrocenyl imines, and ferrocenyl imines having halogen substituents afforded the desired products $\mathbf{1 2 5}$. However, anilines substituted by strong electron withdrawing groups were 50 unreactive.
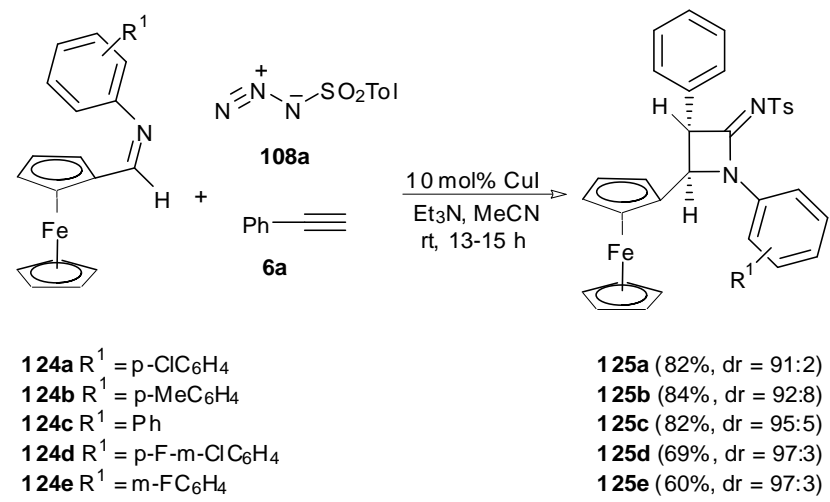

Scheme 43. Stereoselective synthesis of ferrocenyl azetidinimines.

\subsection{Synthesis of four-membered cyclic nitrones}

The group of Terada has described the utility of $(E)-O$ ${ }_{55}$ propargyl arylaldoximes for the preparation of four-membered cyclic $^{\text {nitrones. }}{ }^{54}$ In a preliminary communication ${ }^{55}$ and subsequently in a full paper later, ${ }^{56}$ Terada and co-workers 
reported the copper-catalyzed skeletal rearrangement of $O$ propargyl aryloximes $\mathbf{1 2 6}$ in the presence of $\mathrm{Cu}(\mathrm{I})$ in order to afford the corresponding products 127 and 128. The optimal reaction conditions of the highly regioselective reactions involve 5 the use of $[\mathrm{CuCl}(\mathrm{cod})]_{2}$ in $\mathrm{MeCN}$ at $70{ }^{\circ} \mathrm{C}$ (Scheme 44). Taking into account these results, this group studied the transfer of chirality during the Cu-catalyzed skeletal rearrangement using readily accessible starting materials. For example, the reaction of the corresponding $Z$-isomer $(R, Z)-\mathbf{1 2 6 e}$ provide the enantiomer 10 127e without loss of chirality (Scheme 45).

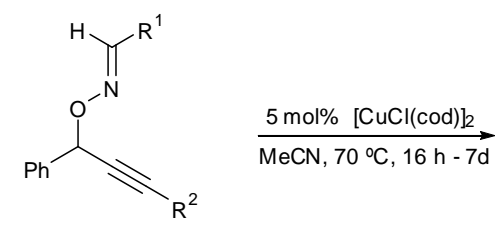

$126 a R^{1}=p-\left(F_{3} C\right) C_{6} H_{4}, R^{2}=p-(M e O) C_{6} H_{4}$ $126 b^{1}=p-\left(F_{3} C\right) C_{6} \mathrm{H}_{4}, \mathrm{R}^{2}=n P r$ $126 \mathrm{c} \mathrm{R}{ }^{1}=\mathrm{p}-\left(\mathrm{F}_{3} \mathrm{C}\right) \mathrm{C}_{6} \mathrm{H}_{4}, \mathrm{R}^{2}=\mathrm{Cy}$ 126 d R$^{1}=$ 2-naphthyl, $\mathrm{R}^{2}=\mathrm{p}-(\mathrm{MeO}) \mathrm{C}_{6} \mathrm{H}_{4}$

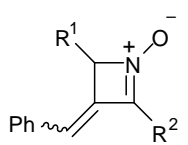

127 $+$

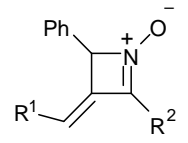

128 127a:128a $(92 \%, d r=98: 2,127 a(E / Z)=74: 26)$ 127b:128b $(91 \%, d r=97: 3,127 b(E / Z)=83: 17)$ 127c: $128 \mathrm{c}(95 \%, \mathrm{dr}=93: 7,127 \mathrm{c}(E / Z)=74: 26)$ 127d:128d $(88 \%, d r=97: 3,127 d(E / Z)=74: 26)$

Scheme 44. Copper-catalyzed reactions of $O$-propargyl aryloximes.

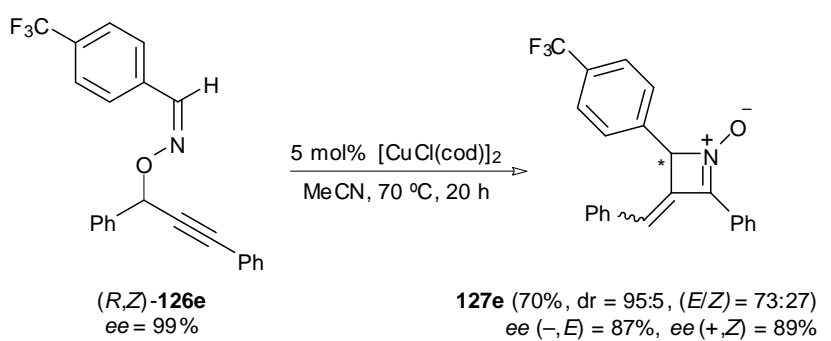

15 Scheme 45. Chirality transfer for copper-catalyzed reaction of $\mathbf{1 2 6 e}$.

A possible pathway for the achievement of the four-membered cyclic nitrones 127 is outlined in Scheme 46. First, the copper catalyst coordinates with the alkyne moiety of $(E)-\mathbf{1 2 6}$ to allow 20 the nucleophilic attack by the oxime nitrogen atom onto the electrophilically-activated triple bond. The resulting fivemembered cyclic intermediate $\mathbf{1 2 9}$ undergoes cleavage of the carbon-oxygen bond and elimination of the copper catalyst to afford $N$-allenylnitrone intermediate 131a, which then rotates to 25 conformer $\mathbf{1 3 1 b}$ that undergoes cyclization to afford product $\mathbf{1 2 7}$. In the case of $(Z)-\mathbf{1 2 6}$, the [2,3] rearrangement proceeds in a concerted manner to form $N$-allenylnitrone intermediate $(Z)-\mathbf{1 3 1 c}$, without the aid of the copper catalyst. Should the cyclization of the chiral allene intermediate $(E)-\mathbf{1 3 1 b}$ proceed via a conrotatory 30 $4 \pi$-electrocyclization, the $\mathrm{sp}^{3}$-carbon would adopt an $S$ configuration. However, the resulting $R$-configuration suggests that the aldonitrone moiety undergoes an $E / Z$ isomerization to favor the more stable $(Z)$-131c prior to the thermal cyclization. The high level of chirality transfer proceeds directly via (Z)- $N$ 35 allenylnitrone intermediate $(Z)-131 c$. At the present stage, it is unclear whether the loss of ee takes place during the coppercatalyzed [2,3] rearrangement step from $(E)-\mathbf{1 2 6}$ to 131.

Scheme 46. Mechanistic outline for the formation of four-membered cyclic nitrones 127. 


\section{Cite this: DOI: 10.1039/c0xx00000x}

ARTICLE TYPE

\section{Conclusions}

During the last years, significant progress has been made in the exploration of copper-promoted-reactions. For this reason, this review has summarized a $\mathrm{Cu}$-assisted synthesis of strained four-

5 membered nitrogen heterocycles. The most important aspect of copper chemistry lies in its efficiency, since the reaction can be performed at ambient temperature. It should be noted, that the majority of reactions described here, proceeds under relatively mild conditions and tolerates a wide variety of functional groups.

10 The presently available report on $\mathrm{Cu}$-promoted-reactions covered the synthesis of $\beta$-lactams by Kinugasa reaction, from Ullmantype coupling, via an oxidative process and synthesis of azetidines derivatives. Considering the sustained interest in the application of available copper salts for the synthesis of four15 membered azacycles, much broader applications will be expected in the future.

\section{Abreviations}

$\begin{array}{ll}\text { Ar: } & \text { aryl } \\ \text { Bn: } & \text { benzyl } \\ { }_{20} \text { Cu(aca) } & \text { copper(II) acetylacetonate } \\ \text { CAN: } & \text { ceric ammonium nitrate } \\ \text { Cbz: } & \text { benzyloxycarbonyl } \\ \text { Cy: } & \text { ciclohexyl } \\ \text { DBU: } & \text { 1,8-diazabicyclo[5.4.0]undec-7-ene } \\ \text { 25 DCC: } & N, N \text {-Dicyclohexylcarbodiimide } \\ \text { DCE: } & \text { 1,2-Dichloroethane } \\ \text { DIC: } & N, N \text {-Diisopropylcarbodiimide } \\ \text { DMAP: } & \text { 4-dimethylaminopyridine } \\ \text { DMDEA: } & N, N \text {-dimethylethylendiamine } \\ \text { DMF: } & \text { dimethylformamide } \\ \text { DMG: } & N, N \text {-Dimethylglycine } \\ \text { DMSO: } & \text { dimethyl sulfoxide } \\ \text { dppe: } & \text { (diphos) 1,2-Bis(diphenylphosphino)ethane } \\ \text { dppp: } & \text { 1,3-Bis(diphenylphosphino)propane } \\ \text { 3r: } & \text { diastereomeric ratio } \\ \text { ee: } & \text { enantiomeric excess } \\ \text { EDC: } & \text { 1-[3-dimethyl aminopropyl]-3-ethylcarbodiimide } \\ \text { Epa: } & \text { 4-ethoxycarbonylanilinomethyl } \\ \text { equiv: } & \text { equivalents } \\ \text { 40 ETA: } & \text { ethanolamine } \\ \text { Hmp: } & \text { 4-hydroxi-1-methylpiperidin-4-ylmethyl } \\ \text { HOBT: } & 1 \text {-hydroxybenzotriazole } \\ \text { IBD: } & \text { iodobenzene diacetate } \\ \text { MCR } & \text { multicomponent reaction } \\ \text { MS: } & \text { mesyl } \\ \text { PMP: } & \text { molecular sieves } \\ \text { Py: } & \text { pyridine } \\ \text { r: } & \text { ratio } \\ & \end{array}$

$\begin{array}{ll}\text { 50 rt: } & \text { room temperature } \\ \text { SDS: } & \text { sodium dodecyl sulphate } \\ \text { TBDPS: } & \text { tert-butyldiphenylsilyl } \\ \text { TBS: } & \text { tert-butyldimethylsilyl } \\ \text { THF: } & \text { tetrahydrofuran } \\ \text { 55 TMG: } & N, N, N^{\prime}, N^{\prime} \text {-tetramethylguanidine } \\ \text { Tol: } & \text { tolyl } \\ \text { TOX: } & \text { trisoxazoline } \\ \text { Ts: } & \text { tosyl }\end{array}$

\section{Acknowledgements}

60 Support for this work by the MINECO (Projects CTQ201233664-C02-01 and CTQ2012-33664-C02-02), and Comunidad Autónoma de Madrid (Project S2009/PPQ-1752) are gratefully acknowledged.

\section{Notes and references}

${ }_{65}{ }^{a}$ Grupo de Lactamas y Heterociclos Bioactivos, Departamento de Química Orgánica I, Unidad Asociada al CSIC, Facultad de Química, Universidad Complutense de Madrid, 28040-Madrid, Spain. Fax: + 34 91 3944103; Tel: + 3491 3944314; E-mail:

alcaideb@quim.ucm.es

$70{ }^{b}$ Instituto de Química Orgánica General, IQOG-CSIC, Juan de la Cierva 3, 28006-Madrid, Spain. Tel: + 3491 5618806, ext 381; E-mail:

Palmendros@iqog.csic.es

1 M. Beller and C. Bolm, Transition Metals for Organic Synthesis, ed.; Wiley-VCH: Weinheim, 2004.

2 (a) I. Goldberg, Ber. Dtsch. Chem. Ges., 1906, 39, 1691; (b) F. Ullmann, Ber. Dtsch. Chem. Ges. 1903, 36, 2382.

3 I. P. Beletskaya and A. V. Cheprako, Organometallics, 2012, 31, 7753.

4 N. R. Deprez, D. Kalyani, A. Krause and M. S. Sanford, J. Am. Chem. Soc., 2006, 128, 4972.

5 R. J. Phipps, N. P. Grimster and M. J. Gaunt, J. Am. Chem. Soc., 2008, 130, 8172.

6 (a) A. J. Hickman and M. S. Sanford, Nature, 2012, 484, 177. (b) R. J. Phipps and M. J. Gaunt, Science, 2009, 323, 1593; (c) F. Monnier and M. Taillefer, Angew. Chem. Int. Ed., 2008, 47, 3096; (d) I. P. Beletskaya and A. V. Cheprakov, Coord. Chem. Rev. 2004, 248, 2337; (e) H. J. Cristau, P. P. Cellier, J.-F. Spindler and M. Taillefer, Chem. Eur. J., 2004, 10, 5607; (f) F. Monnier and M. Taillefer, Angew. Chem., 2003, 120, 3140; (g) S. V. Ley and A. W. Thomas, Angew. Chem. Int. Ed., 2003, 42, 5400; (h) S. V. Ley and A.W. Thomas, Angew. Chem., 2003, 115, 5558.

7 (a) B. Alcaide and P. Almendros, In Progress in Heterocyclic Chemistry, G. W. Gribble, J. A. Joule, ed.; Elsevier: Oxford, 2009; (b) A. Brandi, S. Cicchi and F. M. Cordero, Chem. Rev. 2008, 108, 3988.

8 (a) B. Alcaide, C. Aragoncillo and P. Almendros, In Comp. Heterocycl. Chem. $3^{\text {st }}$ edn., A. R. Katritzky, C. A. Ramsden, E. F. V. Scriven, R. Taylor, ed.; Elsevier: Oxford, 2008; (b) J. MarchandBrynaert and C. Brulé, In Comp. Heterocycl. Chem. $3^{\text {st }}$ edn. A. R. Katritzky, C. A. Ramsden, E. F. V. Scriven, R. Taylor, ed.; Elsevier: Oxford, 2008; (c) J. A. Moore and R. S. Ayers, In Chemistry of Heterocyclic Compounds: Small Ring Heterocycles, Part 2. A. Hassner, ed.; Wiley-VCH: Weinheim, 2008. 
9 (a) G. S. Singh, Mini-Rev. Med. Chem. 2004, 4, 69; (b) G. S. Singh, Mini-Rev. Med. Chem. 2004, 4, 93; (c) D. Niccolai, L. Tarsi and R. J. Thomas, Chem Commun. 1997, 2333; (d) R. Southgate, Contemp. Org. Synth. 1994, 1, 417; (e) R. Southgate, C. Branch, S. Coulton and E. Hunt, Recent Progress in the Chemical Synthesis of Antibiotics and Related Microbial Products, G. Lukacs, ed., Springer: Berlin, 1993; ( $f$ ) Page I, The Chemistry of $\beta$-Lactams, ed.; Chapman and Hall: London, 1992; $(\mathrm{g})$ R. B. Morin and M. Gorman, Chemistry and Biology of $\beta$-Lactam Antibiotics, ed.; Academic: New York 1982.

10 (a) P. C. Hogan and E. J. Corey, J. Am. Chem. Soc., 2005, 127, 15386; (b) J. W. Clader, J. Med. Chem., 2004, 47, 1; (c) L. Kvaerno, T. Ritter, M. Werder, H. Hauser and E. M. Carreira, Ang. Chem. Int. Ed., 2004, 43, 4653; (d) D. A. Burnett, Curr. Med. Chem., 2004, 11, 1873; (e) G. Veinberg, M. Vorona, I. Shestakova, I. Kanepe and E. Lukevics, Curr. Med. Chem., 2003, 10, 1741; (f) M. I. Page and A. P. Laws, Tetrahedron, 2000, 56, 5631; (g) T. M. Haley, S. J. Angier, A. D. Borthwick, R. Singh and R. G. Micetich, Drugs, 2000, 3, 512.

11 J. D. Rothstein, S. Patel, M. R. Regan, C. Haenggeli, Y. H. Huang, D. E. Bergles, L. Jin, M. D. Hoberg, S. Vidensky, D. S. Chung, S. V. Toan, L. I. Bruijn, Z.-Z. Su, P. Gupta and P. B. Fisher, Nature, 2005, 433, 73.

12 (a) A. Kamatha and I. Ojima Tetrahedron, 2012, 68, 10640. (b) B. Alcaide and P. Almendros, Chem Rec., 2011, 11, 311; (c) B. Alcaide, P. Almendros and C. Aragoncillo, Chem Rev., 2007, 107, 4437; (d) B. Alcaide and P. Almendros, Curr. Med. Chem., 2004, 11, 1921; (e) A. R. A. S. Deshmukh, B. M. Bhawal, D. Krishnaswamy, V. V. Govande, B. A. Shinkre and A. Jayanthi, Curr. Med. Chem., 2004, 11, 1889; (f) B. Alcaide and P. Almendros, Synlett, 2002, 381; (g) C. Palomo, J. M. Aizpurua, I. Gamboa and M. Oiarbide, Synlett, 2001, 1813; (h) B. Alcaide and P. Almendros, Chem. Soc. Rev., 2001, 30, 226; (i) C. Palomo, J. M. Aizpurua, I. Gamboa and M. Oiarbide, Amino-acids, 1999, 16, 321; (j) I. Ojima and F. Delaloge, Chem. Soc. Rev., 1997, 26, 377; (k) M. S. Manhas, D. R. Wagle, J. Chiang and A. K. Bose, Heterocycles, 1988, 27, 1755.

13 M. Kinugasa and S. Hashimoto, J. Chem. Soc. Chem. Commun., 1972, 466.

14 L. K. Ding and W. J. Irwin, J. Chem. Soc., Perkin Trans. 1, 1976, 2382.

15 A. Mames, S. Stecko, P. Mikolajezyk, M. Soluch, B. Furman and M. Chmielewski, J. Org. Chem., 2010, 75, 7580.

16 K. Okuro, M. Enna, M. Miura, and M. Nomura, J. Chem. Soc., Chem. Commun. 1993, 1107.

17 C. S. McKay, D. C. Kennedy and J. P. Pezacki, Tetrahedron Lett., 2009, 50, 1893

18 A. Basak, K. Chandra, R. Pal and S. C. Ghosh, Synlett, 2007, 1585.

19 M. Miura, M. Enna, K. Okuro and M. Nomura, J. Org. Chem., 1995, 60, 4999.

20 M. M.-C. Lo and G. C. Fu, J. Am. Chem. Soc., 2002, 124, 4572.

21 M.-C. Ye, J. Zhou, Z.-Z. Huang and Y. Tang, Chem. Commun., 2003, 2554; J. Zhou and Y. Tang, Top Organomet. Chem., 2011, 36, 287.

22 M.-C. Ye, J. Zhou and Y. Tang, J. Org. Chem., 2006, 71, 3576.

23 J.-H. Chen, S.-H. Liao, X.-L. Sun, Q. Shen and Y. Tang, Tetrahedron, 2012, 68, 5042.

24 T. Saito, T. Kikuchi, H. Tanabe, J. Yahiro and T. Otani, Tetrahedron Lett., 2009, 50, 4969.

25 Z. Chen, L. Lin, M. Wang, X. Liu and X. Feng, Chem. Eur. J., 2013, 19, 7561.

26 A. Basak and S. C. Ghosh, Synlett, 2004, 1637.

27 A. Basak, S. C. Ghosh, A. K. Das and V. Bertolasi, Org. Biomol.Chem., 2005, 3, 4050.

28 X. Zhang, R. P. Hsung, H. Li, Y. Zhang, W. L. Johnson and R. Figueroa, Org. Lett., 2008, 10, 3477.

29 M. Michalak, M. Stodulski, S. Stecko, A. Mames, I. Panfil, M. Soluch, B. Furman and M. Chmielewski, J. Org. Chem., 2011, 76, 6931.

30 M. Michalak, M. Stodulski, S. Stecko, M. Woznica, O. StaszewskaKrajewska, P. Kalicki, B. Furman, J. Frelek and M. Chmielewski, Tetrahedron, 2012, 68, 10806.
31 S. Stecko, A. Mames, B. Furman and M. Chmielewski, J. Org. Chem., 2008, 73, 7402.

32 S. Stecko, A. Mames, B. Furman and M. Chmielewski, J. Org. Chem., 2009, 74, 3094.

33 M. Maciejko, S. Stecko, O. Staszewska-Krajewska, M. Jurezak, B. Furman and M. Chmielewski, Synthesis, 2012, 44, 2825.

34 R. K. Khangarot and K. Kaliappan, Eur. J. Org. Chem., 2011, 6117.

35 B. Grzeszczyk, K. Polawska, Y. M. Shaker, S. Stecko, A. Mames, M. Woźnica, M. Chmielewski and B. Furman, Tetrahedron, 2012, 68, 10633.

36 R. Pal and A. Basak, Chem. Commun., 2006, 2992.

37 R. Shintani and G. C. Fu, Angew. Chem. Int. Ed., 2003, 42, 4082.

38 D. Worgull, G. Dickmeiss, K. L. Jensen, P. T. Franke, N. Holub and K. A. Jørgensen, Chem. Eur. J., 2011, 17, 4076.

39 Q. Zhao and C. Li, Org. Lett., 2008, 10, 4037.

40 Z. Xu, K. Huang, T. Liu, M. Xie and H. Zhang, Chem. Commun., 2011, 47, 4923

41 (a) B. Alcaide and P. Almendros, In Progress in Heterocyclic Chemistry, G. W. Gribble, J. A. Joule, ed.; Elsevier: Oxford, 2012; (b) J. T. Lowe, M. D. Lee, L. B. Akella, E. Davoine, E. J. Donckele, L. Durak, J. R. Duvall, B. Gerard, E. B. Holson, A. Joliton, S. Kesavan, B. C. Lemercier, H. Liu, J.-C. Marie, C. A. Mulrooney, G. Muncipinto, M. Welzel-O'Shea, L. M. Panko, A. Rowley, B.-C. Suh, M. Thomas, F. F. Wagner, J. Wei, M. A. Foley and L. A. Marcaurelle, J. Org. Chem., 2012, 77, 7187; (c) M. Packiarajana, C. G. Mazza Ferreira, S.-P. Hong, A. D. White, G. Chandrasena, X. Pu, R. M. Brodbeck and A. J. Robichaud, Bioorg. Med. Chem. Lett., 2012, 22, 6469; (d) B. Alcaide, P. Almendros and C. Aragoncillo, Curr. Opin. Drug. Disc. 2010, 13, 685; (e) G. S. Singh, M. D’Hooghe, N. De Kimpe, In Comp. Heterocycl. Chem. III, eds.; A. R. Katritzky, C. A. Ramsden, E. F. V. Scriven, R. Taylor, Elsevier: Oxford, 2008; (e) D. Ferraris, S. Belyakov, W. X. Li, E. Oliver, Y. S. Ko, D. Calvin, S. Lautar, B. Thomas and C. Rojas, Curr. Top. Med. Chem., 2007, 7, 597; (f) F. Couty and G. Evano, Org. Prep. Proced. Int., 2006, 38, 427; ( $g$ ) F. Couty, F. Durrat and G. Evano, Targets Heterocycl. Syst., 2005, 9, 186; (h) N. De Kimpe, In Comprehensive Heterocyclic Chemsitry II, ed.; A. Padwa, Elsevier: Oxford, 1996; (i) D. E. Davies and R. C. Starr, In Comprehensive Heterocyclic Chemsitry, ed.; W. Lwowski, Pergamon: Oxford, 1984.

42 H. Lu and C. Li, Org. Lett., 2006, 8, 5365.

43 T. Akiyama, K. Daidouji and K. Fuchibe, Org. Lett., 2003, 5, 3691.

44 C. J. Moody, Angew. Chem. Int. Ed., 2007, 46, 9148.

45 A. C. B. Burtoloso and C. R. D. Correia, Tetrahedron Lett., 2004, 45, 3355.

46 A. C. B. Burtoloso and C. R. D. Correia, Synlett, 2005, 1559.

47 M. Whiting and V. V. Fokin, Angew. Chem. Int. Ed., 2006, 45, 3157.

48 (a) I. Yavari and M. Nematpour, Synlett, 2013, 1420; (b) I. Yavari and M. Nematpour, Synlett, 2012, 2215.

49 X. Xu, D. Cheng, J. Li, H. Guo and J. Yan, Org. Lett., 2007, 9, 1585.

50 (a) E. J. Yoo, I. Bae, S. H. Cho, H. Han and S. Chang, Org. Lett., 2006, 8, 1347; (b) S. H. Cho, E. J. Yoo, I. Bae and S. Chang, J. Am. Chem. Soc., 2005, 127, 16046; (c) I. Bae, H. Han and S. Chang, J. Am. Chem. Soc., 2005, 127, 2038.

51 X. Yi, B-D. Barry, P. Liao and X. Bi, Synthesis, 2012, 44, 1323.

52 Y. Xing, H. Zhao, Q. Shang, J. Wang, P. Lu and Y. Wang, Org. Lett., 2013, 15, 2668.

53 S. Gouthaman, P. Shanmugam and A. B. Mandal, Tetrahedron Lett., 2013, 54, 3007.

54 (a) I. Nakamura, T. Araki and M. Terada, J. Am. Chem. Soc., 2011, 133, 6861. (b) I. Nakamura, T. Araki and M. Terada, J. Am. Chem. Soc., 2009, 131, 2804 (withdrawn).

55 I. Nakamura, T. Araki, D. Zhang, Y. Kudo, E. Kwon and M. Terada, Org. Lett., 2011, 13, 3616.

56 I. Nakamura, Y. Kudo, T. Araki, D. Zhang, E. Kwon and M. Terada, Synthesis, 2012, 44, 1542. 
Autores: Alcaide, B.; Almendros, P.; Luna, A.

Título: Novel Achievements with an Old Metal: Copper-Promoted Synthesis of Four-Membered Azacycles

Revista: RSC Adv. 2014, 4, 1689-1707;

DOI: $10.1039 / \mathrm{C} 3 \mathrm{RA} 43861 \mathrm{~A}$ 